\title{
UNA VISIÓN DE LA LIBERTAD DE COMUNICACIÓN DESDE LA PERSPECTIVA DE LAS DIFERENCIAS ENTRE LA LIBERTAD DE EXPRESIÓN, EN SENTIDO ESTRICTO, Y LA LIBERTAD DE INFORMACIÓN
}

JOSÉ LUIS GARCÍA GUERRERO

Profesor Titular de de Derecho Constitucional Universidad de Castilla La Mancha

\author{
SUMARIO \\ I. Introducción. \\ II. Las diversas formas de comunicación \\ constitucionalizadas. \\ III. La libertad de expresión, en sentido es- \\ tricto, y el derecho a comunicar y recibir \\ libremente información veraz.
}

\section{INTRODUCCIÓN}

Se podría considerar que la mayor parte de los derechos de libertad y políticos se aglutinan en torno a tres o cuatro grandes géneros y sus correspondientes garantías. Dentro de cada género, habría, lógicamente, diferentes especies. Si esto fuera así se comprendería que la mayor parte de los sistemas constitucionales occidentales compartan unos sistemas de derechos y libertades fundamentales semejantes, a pesar de que sus constituciones presentan divergencias a la hora de constitucionalizar los referidos derechos; diferencias que se difuminan por los trabajos de la literatura jurídica y, especialmente, de la jurisprudencia constitucional que, atendiendo a una imperiosa demanda de la sociedad, desarrollan del tronco común las diferentes especies que la norma fundamental no considero necesario constitucionalizar. También se entenderían las grandes semejanzas en el régimen jurídico de distintas especies de derechos pertenecientes a un mismo género - a veces las diferencias se limitan a las restricciones-y, con seguridad, se estaría en mejores condiciones 
de afrontar las dificultades que las nuevas tecnologías originan a las concepciones clásicas de los derechos.

La libertad de comunicación, entendida en un sentido muy amplio, y constitucionalizada en el artículo 20, es uno de los troncos comunes, uno de los tres o cuatro grandes géneros de que son desarrollo una parte destacada de las diferentes especies de derechos y libertades. En todos los casos, esta libertad comprende la emisión de un mensaje y la recepción por sus destinatarios. La materia sobre la que verse, su finalidad, el tipo de soporte empleado, y su ejercicio individual o colectivo dan lugar a muy diferentes especies de derechos, pero todos pertenecen al mismo género: el de la libertad de comunicación. Comparten un régimen jurídico o status jurídico sustancialmente análogo, las variantes de éste explican las diferentes especies, esto es, nuevos derechos y, muchas veces, su correspondiente constitucionalización. En los países en que ésta no se ha producido, la jurisprudencia se ha encargado de su desarrollo. Todos estos derechos que se han agrupado en torno a la libertad de comunicación, entendida en un sentido muy amplio, pueden, a su vez, aglutinarse en dos grandes bloques.

Un primer gran bloque que engloba principalmente a la libertad de expresión en sentido estricto y a la libertad de información. Aunque existen otras formas de comunicación caracterizadas por su objeto, es decir, por la materia a que se refieren y por la finalidad que persiguen, que no han merecido una constitucionalización expresa; en cambio, otras sí. Ejemplos de las primeras son la libertad de expresión en el ejercicio de la defensa letrada, así como la publicidad comercial, entre otras. Ejemplos de las segundas, el derecho a la producción y creación literaria, artística, científica y técnica; la libertad de cátedra, que a su vez se conecta, de una parte, con el derecho anterior, y, de otra, con la libertad de educación ${ }^{1}$; y, la libertad de expresión religiosa e ideológica, entre otras.

El segundo gran bloque se centra en el derecho de reunión, que se caracteriza por su ejercicio colectivo, con pluralidad de emitentes y destinatarios del mensaje y por el medio empleado, un lugar cerrado o acotado. El derecho de asociación es una derivación del anterior que se singulariza por ser una reunión de carácter permanente. El derecho de sindicación específica al de asociación y se caracteriza por la dimensión institucional y por su finalidad, proteger a los trabajadores -el principal medio para ello es la huelga, razón por lo que en el mismo artículo se procede a su constitucionalización como derecho. La libertad de culto es derivación, a su vez, de la libertad de reu-

1 SANTAOLALLA LÓPEZ, Fernando, "Jurisprudencia del Tribunal Constitucional sobre la libertad de expresión; una valoración", Revista de Administración Pública, núm. 128, 1992, p. 186, coincide con esta vinculación señalada en el texto: «La educación y la creación literaria, artística, científica y técnica son uno de los vehículos a través de los que se transmite el pensamiento humano, por lo que si se reconoce la libre expresión de este último, embebido está el reconocimiento de estas proyecciones. Con ello no quiere decirse que sea inútil este doble reconocimiento, pues el mismo puede servir al mejor afianzamiento de la libertad básica, actuando como recordatorio de que esas muestras son sólo reflejo de ese haz fundante». 
nión, asociación y expresión, en sentido amplio, empleados con finalidad religiosa. La libertad de manifestación es una forma de ejercitar la libertad de expresión, entendida en sentido amplio, para los que carecen de medios económicos. Sin haber merecido, por parte de la Constitución, la caracterización de fundamentales, también son desarrollo del derecho de asociación, en virtud del fin perseguido, las fundaciones del artículo 34, los colegios profesionales del 36, y las empresas del 38. El derecho de reunión y el de asociación no son derechos condición del ejercicio de los derechos políticos. Tienen una vertiente institucional, en palabras de nuestro Tribunal Constitucional —posición que, como se verá, no comparto-, al igual que la libertad de expresión, en sentido amplio, y cuando se utilizan con finalidad política adquieren poderes exorbitantes.

Explicito esta opinión - las diferentes especies de derechos en torno a tres o cuatro géneros o troncos comunes-, a pesar de las dudas que sigue suscitándome, porque lo que se inició como una intuición va tornándose una convicción a medida que profundizo en el estudio de los derechos y libertades fundamentales. A su favor, juegan las diversas formas de comunicación constitucionalizadas; y, en su contra, la autorizada opinión del profesor Rubio Llorente cuando manifestó que «el poder constituyente, en un principio, y la jurisprudencia constitucional, posteriormente, han extendido indebidamente el derecho a una libre comunicación a todo tipo de actividades" ${ }^{2}$.

Este escrito, tras explicitar las diversas formas de comunicación constitucionalizadas más las desarrolladas por la jurisprudencia constitucional, se va a centrar en lo que se conoce como libertad de expresión, en sentido amplio; esto es, en las formas de comunicación más clásicas que engloban la libertad de expresión, en sentido estricto, y la libertad de información ${ }^{3}$. La exposición trata de poner el acento en aquello que comparten y, sobre todo, que distingue a estas dos formas de comunicación; aprovechando para tratar de explicar las muy diferentes restricciones que se imponen a las diversas formas de comunicación.

\section{LAS DIVERSAS FORMAS DE COMUNICACIÓN CONSTITUCIONALIZADAS}

El artículo 20.1 de la Constitución española establece: "Se reconocen y protegen los derechos: a) A expresar y difundir libremente los pensamientos,

2 Una primera redacción de este trabajo se expuso en dos sesiones del Seminario de profesores de Derecho Constitucional, que se celebra en la Universidad Autónoma de Madrid, bajo la dirección de los profesores RUBIO LLORENTE y ARAGÓN REYES. En la citada reunión manifestó la opinión reflejada en el texto.

3 Véase, entre otros, SOLOZÁBAL ECHAVARRÍA, Juan José, "La libertad de expresión desde la teoría de los derechos fundamentales", Revista Española de Derecho Constitucional, núm. 32, p. 81. 
ideas y opiniones mediante la palabra, el escrito o cualquier otro medio de reproducción. [...] d) A comunicar o recibir libremente información veraz por cualquier medio de difusión".

Nuestra Norma Fundamental garantiza, con carácter general, en estos apartados la libertad de expresión, entendida en sentido amplio o, mejor aún, el derecho a una libre comunicación. Y digo que protege con carácter general, porque, en mi opinión, como se acaba de señalar, el poder constituyente, en un principio, y la jurisprudencia constitucional, posteriormente, han extendido el derecho a una libre comunicación a todo tipo de actividades. De tal forma que en nuestro sistema jurídico existen otras formas de comunicación, caracterizadas por su objeto, esto es, por la materia a que se refieren ${ }^{4}$ y que en unos casos no han merecido una constitucionalización expresa ${ }^{5}$ - por ejemplo, la libertad de expresión en el ejercicio de la defensa letrada-y, en cambio, en otros sí. Respecto a éstos, los dos primeros se contienen en el propio artículo 20.1., concretamente, en los apartados b) y c).

El apartado b) del artículo 20.1 reconoce el derecho "A la producción y creación literaria, artística, científica y técnica ${ }^{6}$. El derecho aquí reconocido se debe conectar con el principio rector de la política económica y social sancionado en el artículo $44 \mathrm{CE}$ «1. Los poderes públicos promoverán y tutelarán el acceso a la cultura, a la que todos tienen derecho. 2. Los poderes públicos promoverán la ciencia y la investigación científica y técnica en beneficio del interés general".

4 En el mismo sentido, la STC 157/1996, FJ 5. ${ }^{\circ}$, de 15 de octubre: "En efecto, junto a los supuestos ordinarios de ejercicio de la libertad de expresión como forma genérica, exteriorizada, de una previa libertad de opinión o de creencia, se dan supuestos de ejercicio de tal libertad en los que están implicados otros bienes constitucionales, o incluso otros derechos fundamentales. Tal es el caso de la libertad de expresión conectado a los procesos de formación y de exteriorización de un poder político democrático (art. $23 \mathrm{CE}$ ), el de la libertad de cátedra (art. $20.1 \mathrm{c}$ ), o el que ahora nos ocupa de la defensa y asistencia de letrado".

5 Por ejemplo, la STC 38/1988, FJ $2 .^{\circ}$ y $3 .^{\circ}$, de 9 de marzo, conecta los artículos 20.1 a) y 24.2 para extraer un derecho de libertad de expresión y defensa, "en cuanto ejercitada al servicio de garantías establecidas en el art. 24 CE". Hay una "libertad de expresión de que es titular el Abogado en cuanto tal", de la que derivan límites diversos, por ejemplo, al realizar la concordancia práctica con bienes como el respeto debido a las demás personas que participan también en la función de administrar justicia. La STC 205/1994, FJ 6. ${ }^{\circ}$, de 11 de julio, aclara que esta conexión dota a la libertad de expresión de una especial resistencia que la hace inmune a restricciones que operarían en otro contexto siempre que se atenga a la finalidad que la origina. No obstante, se imponen como límites el que no se provoquen dilaciones indebidas, se altere el orden público o se atente a la imparcialidad del Tribunal. Véase SSTC 288/1994, FJ $2 .^{\circ}$ y $3 .^{\circ}$, de 27 de octubre; 92/1995, FJ $1 .^{\circ}$ y $2 .^{\circ}$, de 19 de junio; $120 / 96$, FJ $10 .^{\circ}$, de 8 de julio; $113 / 2000$, FJ $4 .^{\circ}$, de 5 de mayo; $117 / 2003$, FJ $3 .^{\circ}$ de 16 de junio; 65/2004, FJ $3 .^{\circ}$, de 19 de abril; 232/2005, FJ $3 .^{\circ}$ Y $4 .^{\circ}$, de 26 de septiembre; $155 / 2006$, FJ $4 .^{\circ}$ y $5 .^{\circ}$, de 22 de mayo; $338 / 2006$, FJ $2 .^{\circ}$ y $3 .^{\circ}$, de 11 de diciembre; $24 / 2007$, FJ $2 .^{\circ}$ y $3 .^{\circ}$, de 12 de febrero, especialmente.

6 Este precepto encuentra protección, entre otras muchas disposiciones, en el art. 270 del Código Penal y en el Real Decreto Ley 1/1996, de 12 de abril, por el que se aprueba el texto refundido de la Ley de la Propiedad Intelectual, regularizando, aclarando y armonizando las disposiciones legales vigentes sobre la materia. 
Su régimen jurídico no presenta diferencias respecto al general, según dispone la STC $153 / 85$, FJ $5 .^{\circ}$, cuando afirma que el apartado b) es una mera concreción del derecho reconocido en el apartado a). No obstante, frente a este pronunciamiento hay elementos para pensar que el régimen general de este derecho puede presentar variaciones sustanciales respecto al de la comunicación constitucionalizado en los apartados a) y d) del propio artículo 20. El Magistrado RUBIO LLORENTE formuló voto particular a la sentencia citada, señalando: "A mi juicio, ni la libertad de producción y creación literaria, artística, etc., es una concreción del derecho a expresar y difundir libremente el pensamiento, sino [que es] un derecho autónomo,.... ${ }^{7}$. Y la STC 43/2004, FJ $5 .^{\circ}$, tras indicar que el apartado b) es reiteración del a), añade, muy significativamente, que la libertad científica histórica — hasta ahora se había referido a la libertad literaria- disfruta de una protección acrecida respecto de la que opera para las libertades de expresión e información cuando entra en conflicto con los derechos de la personalidad, pues éstos, al menos constitucionalmente, se han ido diluyendo con el paso del tiempo y no pueden oponerse con el mismo alcance e intensidad. El ATC 197/82 ha excluido de esta libertad los derechos de propiedad intelectual e industrial; y el mismo FJ 5 . $^{\circ}$ de la STC 153/85, incluye en el ámbito del derecho no sólo la impresión gráfica de una obra teatral, sino, también, su representación pública.

La otra forma de comunicación, que sí ha merecido una constitucionalización expresa, se encuentra en el apartado c) del artículo 20.1, donde se reconoce y protege el derecho "A la libertad de cátedra", que a su vez se conecta con el apartado b) y con el derecho a la educación, consagrado en el artículo $27^{8}$. En este último caso, se está en presencia, sin duda, de una comunicación'; pero el constituyente ha considerado oportuno regular específicamente las que tienen por ámbito y finalidad la materia educativa. Su régimen general es propio y presenta sustanciales diferencias frente al de la comunicación. Lo demuestra la especial protección otorgada al comunicador educativo mediante la libertad de cátedra y ciertas especificaciones referidas a los límites: deben respetarse los principios democráticos y los derechos y libertades fundamentales; la educación debe tener por objeto el pleno desarrollo de la personalidad humana; los padres deciden qué conocimientos religiosos y morales se transmiten a sus hijos. Así lo reconoce la STC 5/81,

7 En el mismo sentido que la STC 153/1985, DE CARRERAS, Francesc, "La libertad de expresión un derecho constitucional", Anuario de 1990 sobre la libertad de expresión de la Universidad Autónoma de Barcelona, coordinado por FREIXES SANJUÁN, Teresa, PPU, 1991, pp. 11, 20 y 29, que incluye además el apartado c). En contra y, por tanto, en sintonía con RUBIO LLORENTE, CHINCHILLA MARÍN, Carmen, La radiotelevisión como servicio público esencial, Tecnos, 1988, pp. 24-25, que piensa que nuestra Constitución concibe como derechos y libertades diferentes e independientes los cuatro apartados del art. 20.1.

8 Véase supra nota 1.

9 La STC 5/1981, de 13 de febrero, FJ 7. ${ }^{\circ}$, señala: «La libertad de enseñanza [...] puede ser entendida como una proyección de la libertad ideológica y religiosa y del derecho a expresar y difundir los pensamientos, ideas u opiniones...". 
FJ 7. ${ }^{\circ}$, cuando afirma: «la libertad de enseñanza [ha] de moverse en todos los casos dentro de límites más estrechos que los de la pura libertad de expresión".

Fuera ya del artículo 20, el 16 contempla aquellas comunicaciones que tienen un ámbito y finalidad religiosa, así como las que son expresión de la libertad ideológica. Aquí también nos encontraremos con regímenes propios. El único límite expreso en sus manifestaciones es el necesario para el mantenimiento del orden público protegido por la ley. En materia religiosa, el derecho a la intimidad y la protección de la juventud y de la infancia se entenderán, probablemente, de forma diferente a las demás formas de comunicación. La STC 20/1990, FJ $3 .^{\circ}$ y $5 .^{\circ}$, confirma que la libertad ideológica, consagrada en el artículo 16.1, tiene un correlativo derecho a expresarla, garantizado en el artículo 20.1 a), pero ello no permite entender simplemente absorbido el primer derecho en el último. Aún reconociendo que la libertad ideológica no puede utilizarse para eludir las restricciones del artículo 20.4, es cierto que ésta no tiene más limitación en sus manifestaciones que la necesaria para el mantenimiento del orden público protegido por la ley. La equiparación de limitaciones entre ambas libertades sería una vía por la que se restringiría "la mayor amplitud con que la Constitución configura el ámbito de aquel derecho" ${ }^{10}$

Las diferentes formas de comunicación, ya estén expresamente constitucionalizadas o no, se diferencian no sólo por su objeto, esto es, por la materia a la que se refieren, sino también por el soporte empleado para transmitir el mensaje. En esta línea hay, incluso, derechos constitucionalizados expresamente que pueden considerarse derivación de la libertad de comunicación o una forma específica de ejercicio. La STC $85 / 1988$, FJ 2. ${ }^{\circ}$, en este sentido, señala: "...que bien puede decirse [...] que el derecho de reunión es una manifestación colectiva de la libertad de expresión ejercitada a través de una asociación transitoria, siendo concebido por la doctrina científica como un derecho [...] que opera a modo de técnica instrumental puesta al servicio del intercambio o exposición de ideas, la defensa de intereses o la publicidad de problemas o reivindicaciones, constituyendo, por lo tanto, un cauce del principio democrático participativo...."11.

Este escrito no puede ni pretende ocuparse de las diversas formas de comunicación constitucionalizadas, expresa o implícitamente, sino que se va a centrar en la libertad de expresión, en sentido estricto, y en la libertad de información ${ }^{12}$; analizando su régimen jurídico desde una perspectiva que facilite la diferenciación de ambos derechos.

10 Sobre la relación entre los artículos 16.1 y 20 CE, véanse también las SSTC 105/1990, FJ $4 .^{\circ}$, de 6 de junio, y 173/1995, FJ $1 .^{\circ}$, de 21 de noviembre.

11 En el mismo sentido, la STC 66/1995, FJ 3. ${ }^{\circ}$, de 8 de mayo.

12 Véase en esta materia, SOLOZÁBAL ECHAVARRÍA, Juan José, "Libertad de expresión y derecho a la información", voz de la Enciclopedia Jurídica Civitas, Madrid, 1995. 


\section{LA LIBERTAD DE EXPRESIÓN, EN SENTIDO ESTRICTO, Y EL DERECHO A COMUNICAR Y RECIBIR LIBREMENTE INFORMACIÓN VERAZ}

\section{NATURALEZA JURÍDiCA}

La naturaleza jurídica está condicionada, obviamente, por la tesis que cada uno adopte para fundamentar la libertad de comunicación. La teoría de la verdad de Stuart Mill, el libre desarrollo de la personalidad, y la participación de los ciudadanos en la democracia, son las tres teorías clásicas que han justificado la libertad de comunicación ${ }^{13}$. La primera introduce progresivamente sus elementos en las dos anteriores ${ }^{14}$, la segunda disfruto de un gran predicamento en Europa, la tercera encontró en los Estados Unidos su mayor desarrollo ${ }^{15}$.

La cuestión puede ser controvertida dogmáticamente, pero desde la perspectiva del derecho positivo nuestra Constitución despeja cualquier duda que pudiera existir al acoger, expresamente, como fundamento teórico de los derechos a una libre comunicación la tesis de la dignidad personal y de su libre desarrollo. En ésta se introdujeron, en su momento, los elementos de la teoría de la búsqueda de la verdad. No obstante, por influencia de EEUU y de Alemania, a través del cauce de la jurisprudencia constitucional, asistimos cada día a un mayor protagonismo de la teoría democrática ${ }^{16}$.

En lógica consecuencia, los derechos reconocidos en el artículo 20 de nuestro texto constitucional son un derecho libertad, un derecho defensa, un derecho límite, vinculado directamente a la dignidad de la persona, tal y como confirma una consolidada jurisprudencia, iniciada por la STC 6/1981, FJ $4 .^{\mathrm{o}}{ }^{17}$.

13 Véase BARENDT, Eric, Freedom of Speech, Clarendon Press, Oxford, 1987, pp. 8-23; y TRIBE, Laurence H., American Constitutional Law, Second Edition, Foundation Press, Nueva York, 1988, pp. 785-789. En España, véase GARCÍA GUERRERO, José Luis, "Publicidad y libertad de expresión en el ordenamiento constitucional español", Derecho Privado y Constitución, núm. 10, pp. 129-133; y sobre esta cuestión, en particular, y a propósito de la libertad de expresión, en general, SALVADOR CODERCH, Pablo, El mercado de las ideas, Centro de Estudios Constitucionales, Madrid, 1990, pp. 26 y ss.

14 Aunque la participación de los ciudadanos en la democracia es la tesis predominante en EEUU, SHAUER, Frederick, Free Speech: A philosophical Enquiry, Cambridge UP, 1982, p. 15, destaca como la tesis del marketplace of ideas, variante de la teoría de la verdad, ha tenido una gran influencia en la formación de los fundamentos teóricos de la libertad de expresión en EEUU. Véase, en este sentido, la opinión expresada por los jueces HOLMES J., en Abrams v. United States, 250 U.S., pp. 616 y 630 (1919); BRANDEIS J., en Whitney v. California, 274 U.S., pp. 357, 375-378 (1927); y FRANKFURTER J., en Kovacs v. Cooper, 336 U.S., pp. 77, 95-97 (1949). Consúltese también el trabajo de RABBAN, "The Emergence of Modern First Amendment Doctrine", U. Chi. Law Review, núm. 50, 1983, pp. 1205 y ss.

15 DE CARRERAS, Francesc, "La libertad de expresión un derecho constitucional", ob. cit., p. 16. Véase TOCQUEVILlE, Alexis de, La democracia en América, Alianza Editorial, 1985.

16 BARENDT, Eric, Freedom of Speech, ob. cit., p. 20, realiza esta afirmación a propósito del país germánico.

17 SSTC 12/1982, FJ 3..$^{\circ}$, de 31 de marzo; 74/1982, FJ $2 .^{\circ}$ y $3 .^{\circ}$, de 7 de diciembre; STC 63/1987, FJ 6. ${ }^{\circ}$, de 20 de mayo; 127/1994, FJ 4. ${ }^{\circ}$, de 5 de mayo. 
Esta posición se refuerza, a mi juicio, si se observa el tenor literal del artículo 10.1. La referida dignidad y el libre desarrollo de la personalidad son el fundamento del orden político y de la paz social. La ubicación sistemática del precepto, presidiendo el Título I, sobre los derechos y libertades fundamentales, parece despejar cualquier duda sobre la teoría que nuestra Constitución adopta para justificar la libertad de comunicación ${ }^{18}$.

Ahora bien, el mayor protagonismo de la teoría democrática ha llevado a reconocer que el derecho a la libre comunicación, sin perder su carácter preferente de derecho libertad, está dotado de una vertiente institucional ${ }^{19}$; aspecto que no acabo de compartir ${ }^{20}$. La STC 6/1981, FJ 3. ${ }^{\circ}$, es la primera en afirmarlo en España:

«El artículo $20 \mathrm{CE}$, en sus distintos apartados, garantiza el mantenimiento de una comunicación pública libre, sin la cual quedarían vaciados de contenido real otros derechos que la Constitución consagra, reducidas a formas hueras las instituciones representativas y absolutamente falseado el principio de legitimidad democrática que enuncia el artículo 1.2 de la Constitución y que es la base de toda nuestra ordenación jurídico-política".

"La preservación de esta comunicación pública libre, sin la cual no hay sociedad libre ni, por tanto, soberanía popular, exige la garantía de ciertos derechos fundamentales comunes a todos los ciudadanos y la interdicción con carácter general de determinadas actuaciones del poder ("verbi gratia" las prohibidas en los apartados 2 y 5 del mismo art. 20)".

Esta línea jurisprudencial se mantendrá en las siguientes sentencias, pero en lugar de emplear la expresión "comunicación pública libre" se hablará de "Opinión pública libre", a partir de la STC 12/1982, FJ 3. ${ }^{\circ}$ : "Se ha señalado acertadamente que se trata ante todo de un derecho de libertad [...] Sin embargo, en otro plano significa el reconocimiento y la garantía de una institución política fundamental, que es la opinión pública libre, indisolublemente ligada con el pluralismo político..." ${ }^{21}$.

18 SOLOZÁBAL ECHAVARRÍA, Juan José, "Dignidad de la persona”, ob. cit., p 2489, en el mismo sentido, al señalar: "Esta interpretación reclama también para nuestra Constitución la consideración de "orden vinculante a valores" que reconoce la protección de la libertad y dignidad de la persona como el fin superior de todo derecho".

1910 BVerfGE, p. 118, 1959; 12 BVerfGE, p. 113, 1961; 20 BVerfGE, p. 162, 1966; 43 BVerfGE, p. 130, 1976; 61 BVerfGE, p. 1, 1982. El Tribunal Federal ha llegado a estas posiciones por rendimientos funcionales, evitar el monopolio de los medios de comunicación, colisión de la libertad de expresión del editor con la de los redactores, conflicto de esta libertad con los derechos de la personalidad, etc. y por influencias doctrinales provenientes de la crítica plebiscitaria leibholziana.

20 GARCÍA GUERRERO, José Luis, "Publicidad y libertad de expresión. expresión en el ordenamiento constitucional español", Derecho Privado y Constitución, núm. 10, 1996, tras exponer un estado de la cuestión sobre las teorías que fundamentan a la libertad de comunicación (pp. 129-133), afirma que ésta es sólo un derecho libertad y niega la vertiente institucional, aunque no sus consecuencias, pp. 133-142. Véase también infra pp. 382 y ss., donde se intenta una argumentación ampliada y mejorada.

21 Posteriormente SSTC 104/1986, FJ 5. ${ }^{\circ}$, de 17 de julio; 165/1987, FJ 10. ${ }^{\circ}$, de 25 de octubre; 107/1988, FJ 2. ${ }^{\circ}$, de 8 de junio; 121/1989, FJ $2 .^{\circ}$, de 3 de julio; 40/1992, FJ $1 .^{\circ}$ in fine, de 30 de marzo; 336/1993, FJ 4. ${ }^{\circ}$, de 15 de noviembre; 42/1995, FJ 2. ${ }^{\circ}$, de 13 de febrero; 204/1997, FJ 2. ${ }^{\circ}$, de 25 de noviembre, entre otras muchas. 


\section{Objeto de la COMUNiCACiÓn, TITUlaridad DE los DERECHOS Y POSICIÓN DE LOS PODERES PÚBLICOS EN RELACIÓN CON SU EJERCICIO}

El contenido de la comunicación es indeterminado. Su objeto, como sucede con cualquier derecho libertad, garantiza todo tipo de actividades ${ }^{22}$; es decir, la libre transmisión o comunicación de cualquier tipo de mensaje y su recepción por los destinatarios. Luego, en consecuencia, habrá que ocuparse del emisor - aspecto poco controvertido, que se analizará al hilo de la titularidad-, del medio o soporte que contiene el mensaje — lo que dará lugar a nuevos derechos como la libertad de correspondencia-, de la materia y, por último, del destinatario.

La propia Constitución se ocupa de mencionar a la palabra y al escrito como los soportes más frecuentes empleados para la transmisión de mensajes. Pero consciente de los avances tecnológicos añade muy reveladoramente "O cualquier otro medio de reproducción". Algunos de éstos no plantean problema, pero otros soportes llevaron a que el Tribunal Constitucional se viera obligado muy prontamente a reconocer un derecho instrumental de la libertad de comunicación en conexión con la libertad de empresa: el derecho a crear medios de difusión. Así en la STC 12/1982, FJ 3. ${ }^{\circ}$, señala que "no hay inconveniente en entender que el derecho a difundir las ideas y opiniones comprende en principio el derecho de crear los medios materiales a través de los cuales la difusión se hace posible». Ahora bien, se requiere una precisión a la doctrina del Tribunal, sería más correcto hablar del derecho a crear medios de comunicación en general, y no restringirlo a las ideas y opiniones; por los medios también circulan informaciones y otros muchos mensajes, como ya se ha visto; por ejemplo, sin galerías de arte difícilmente podría hablarse del derecho a pintar cuadros, y así sucesivamente.

Este derecho instrumental a crear medios de difusión tampoco es absoluto y presenta limitaciones, que variarán en función del soporte empleado. La Televisión y la Radio, emitidas por ondas hertzianas, presentan restricciones por lo limitado del espacio radioeléctrico, por el empleo del dominio público, y por los acuerdos internacionales que exigen la concesión de licencias cuando se usa el espacio radioeléctrico ${ }^{23}$. Estas limitaciones serán bastante menores en el caso de las televisiones por cable, en consecuencia, como ha señalado la STC 88/1995, FJ 5.․, las restricciones dependerán en buena medida de

22 SOLOZÁBAL ECHAVARRÍA, Juan José, "Aspectos constitucionales de la libertad de expresión y el derecho a la información", Revista Jurídica de Castilla-La Mancha, núm. 3 y 4, Actas del VI Congreso Nacional de Ciencia Política y Derecho Constitucional, 1988, p. 232, ya señaló que "Respecto del contenido de la comunicación cuya libertad garantiza el artículo 20, no es posible admitir restricción alguna...".

23 Véase CHINCHILLA MARÍN, Carmen, La radiotelevisión como servicio público esencial, ob. cit. ROSADO IGLESIAS, G. La televisión pública en España. Régimen Público y control, Cedecs, Barcelona, 1999. Y HOFFMANN-RIEM, Wolfgang, "La dimensión jurídico-objetiva de la libertad de información y comunicación", Revista Española de Derecho Constitucional, núm. 77, 2006, pp. 121 y ss. 
la evolución tecnológica. Y, por último, en otros casos serán inexistentes, como sucede en el caso de la prensa escrita; su titular puede ejercer el derecho sin mediación del legislador y sin intervención previa de Administración, como señala la STC 77/1982.

No hay, en principio, ningún tipo de discriminación por razón de la materia, dado que el contenido de la comunicación es indeterminado. En realidad, es configurado por su titular. Cuestión diversa serán las limitaciones originadas por la preservación de otros bienes y derechos constitucionales, o las menores restricciones de los mensajes necesarios para la toma de decisiones políticas, lo que puede derivar de la vertiente institucional en palabras del Constitucional.

En lo que se refiere al destinatario, alguna doctrina ha considerado el derecho a recibir información veraz como un derecho subjetivo individual autónomo, extremo que no se puede compartir. Parece más apropiada la jurisprudencia constitucional, que desde la STC 6/1981, FJ 4. ${ }^{\circ}$, reconoció el derecho a informar y ser informado como un derecho individual de doble faz. En concreto el derecho a recibir información se justifica "por el propósito de ampliar al máximo el conjunto de los legitimados para impugnar cualquier perturbación de la libre comunicación social ${ }^{24}$.

Su titularidad es universal en razón de su imprescindibilidad para el libre desarrollo de la personalidad y la dignidad humana. La restricción en favor de los periodistas implicaría confundir ejercicio frecuente con titularidad, como confirma la STC 6/1981, FJ 4..$^{\circ}$ : "Son estos derechos, derechos de libertad frente al poder y comunes a todos los ciudadanos. Quienes hacen profesión de la expresión de ideas u opiniones o de la comunicación de información los ejercen con mayor frecuencia que el resto de sus conciudadanos, pero no derivan de ello ningún privilegio". A pesar de que la sentencia emplea, en sentido amplio y con poca rigurosidad, el término ciudadanos, no hay dudas de que los extranjeros no pueden sufrir limitaciones abusivas en su titularidad; dado que su disfrute se desarrolla en los términos establecidos en los artículos 10 y $13 \mathrm{CE}^{25}$ y por prevalecer la consideración de derecho libertad frente a la vertiente institucional, no se está en presencia de un derecho político.

La libertad de comunicación implica la emisión y recepción de mensajes. Frente al ejercicio de esta actividad compete a los poderes públicos, como regla general, una actitud de abstención y respeto, tal y como dispone la STC 12/1982, FJ 3..$^{\circ}$ : Se ha señalado acertadamente que se trata ante todo de un derecho de libertad, por lo que básicamente significa ausencia de interferencias o de intromisiones de las autoridades estatales en el proceso de comunicación». Y también la STC 77/1982, FJ 1.': «...tal y como está configurada dicha

24 VILLAVERDE MENÉNDEZ, Ignacio, Estado democrático e información: el derecho a ser informado, Junta General del Principado de Asturias, 1994, concibe el derecho a recibir información como un derecho subjetivo individual autónomo.

25 Véase SOLOZÁBAL ECHAVARRÍA, Juan José, "Aspectos constitucionales de la libertad de expresión...", ob. cit., pp. 231-232. 
libertad, el ejercicio de la misma no exige con carácter general más que la pura y simple abstención por parte de la Administración, la ausencia de trabas o impedimentos por parte de ésta [...] Se trata de una de las libertades de los sujetos particulares que no exigen más que una mera actitud de no injerencia por parte de los poderes públicos".

No obstante, es necesaria, excepcionalmente, una intervención de los poderes públicos para garantizar que un tercero no impide la emisión o recepción de mensajes, a través de una función esencialmente tuitiva a la que, ahora, no se puede dedicar especial atención; asegurar el acceso a los medios de comunicación de titularidad pública en cumplimiento del artículo 20.3 CE; garantizar, en determinadas circunstancias, el pluralismo informativo; y, finalmente, posibilitar el disfrute simultáneo del derecho y compatibilizar su ejercicio con otros derechos, bienes y valores constitucionales, de donde dimanan restricciones $^{26}$ y excepciones procesalmente establecidas, para salvar las intervenciones gubernativas o judiciales a su disfrute. A continuación, se examinarán algunas de estas intervenciones con mayor detenimiento, concretamente, las derivadas del $20.3 \mathrm{CE}$ y del pluralismo informativo.

El artículo 20.3 de la Constitución dispone que "La ley regulará la organización y el control parlamentario de los medios de comunicación social dependientes del Estado o de cualquier ente público y garantizará el acceso a dichos medios de los grupos sociales y políticos significativos, respetando el pluralismo de la sociedad y de las diversas lenguas de España " ${ }^{27}$. Ante ello la STC 63/1987, FJ 6. ${ }^{\circ}$, reitera que los poderes públicos deben, como norma general, abstenerse en relación con la libertad de comunicación, pero prevé una intervención excepcional, específicamente del legislador, para regular los medios de comunicación social públicos, de forma que se garantice el acceso de los grupos sociales y políticos significativos, de conformidad con el artículo 20.3 CE. No obstante, como señala la STC 6/1981, FJ 4. ${ }^{\circ}$ y 5..$^{\circ}$, esta disposición no prescribe la necesaria existencia de un sector público, ni al comunicante se le garantiza el derecho a ser oído por todo el mundo o por determinadas personas. El derecho de comunicación no permite la puesta a disposición por parte del Estado de un medio de difusión, de lo contrario, nos encontraríamos ante un derecho prestación y se impediría el funcionamiento eficaz de los medios de comunicación de masas $^{28}$.

Los poderes públicos pueden intervenir, también, en su condición de Estado Social y en virtud del mandato genérico contenido en el artículo 9.2 CE, para garantizar, en determinadas circunstancias, el pluralismo informativo. Lo hacen a través de una actuación estimuladora, mediante ayudas que abaraten los costes de los medios (STC 6/1981, FJ 5.'), y otra correctora, impi-

26 Véase infra, el apartado: Los límites de la libertad de comunicación.

27 Véase MAGDALENO ALEGRíA, Antonio, «El derecho de acceso a los medios de comunicación públicos de los grupos sociales y políticos significativos en el Estado Social y Democrático de Derecho", Teoría y Realidad Constitucional, núm. 18, 2006, pp. 223 y ss.

28 SOLOZÁBAL ECHAVARRÍA, Juan José, "Aspectos constitucionales de la libertad de expresión..., ob. cit., p. 235. 
diendo los monopolios informativos; aspecto, este último, que exige determinar cuando nos encontramos ante esta situación, y las modalidades de intervención, que pueden consistir en la ampliación obligatoria de acciones, la división de la empresa monopolista, la creación de un consejo editor supervisor, o la constitución de nuevas empresas ${ }^{29}$.

Tan de abstención y respeto, como regla general, es la posición de los poderes públicos que el propio artículo $20 \mathrm{CE}$, establece: «2. El ejercicio de estos derechos no puede restringirse mediante ningún tipo de censura previa". "S. Sólo podrá acordarse el secuestro de publicaciones, grabaciones y otros medios de información en virtud de resolución judicial».

La STC 52/1983 resalta el carácter taxativo del apartado $2 .^{\circ}$ en su FJ 5. ${ }^{\circ}$, al disponer "...que la Constitución, precisamente por lo terminante de su expresión, dispone eliminar todos los tipos imaginables de censura previa, aún los más débiles y sutiles, que tengan por efecto no ya el impedimento o prohibición, sino la simple restricción de los derechos de su artículo 20.1.». En el mismo FJ $5 .^{\circ}$ aclara que es la censura previa: "por tal puede entenderse cualquier medida limitativa de la elaboración o difusión de una obra del espíritu, especialmente al hacerla depender del previo examen oficial de su contenido". Posteriormente, la STC 13/1985, FJ $1 .^{\circ}$, precisa como "El "previo examen oficial ... implica la finalidad de enjuiciar la obra en cuestión con arreglo a unos valores abstractos y restrictivos de la libertad, de manera tal que se otorgue el "placet" a la publicación de la obra que se acomode a ellos a juicio del censor y se le niegue en el caso contrario". Esta legitimidad censora no la tienen, ni siquiera, los Tribunales, que sólo pueden adoptar una medida limitativa temporalmente del derecho a la información cuando se trate de preservar otro bien o derecho constitucional.

La STC 144/1987, FJ 3. ${ }^{\circ}$, ha aclarado que el secuestro se refiere a publicaciones, grabaciones o cualquier otro soporte, pero no contra el medio que lo produce, fotocopiadoras, impresoras, emisoras de radio y televisión.

\section{LA LIBERTAD DE EXPRESIÓN, EN SENTIDO ESTRICTO, Y EL DERECHO A COMUNICAR Y RECIBIR INFORMACIÓN VERAZ SE DIFERENCIAN, FUNDAMENTALMENTE, POR SU OBJETO}

La jurisprudencia del Tribunal Constitucional, en un primer momento, consideró que el derecho a comunicar información era una concreción del derecho a la libertad de expresión, y que el derecho a recibir la información era un simple reverso del derecho a transmitirla, dado que no es posible la recepción sin la comunicación ${ }^{30}$.

29 Véase en este punto las interesantes notas de SOLOZÁBAL ECHAVARRÍA, Juan José, "Aspectos constitucionales de la libertad de expresión..., ob. cit., pp. 237-238, que sigue en este punto a HERZOG, dentro de la doctrina alemana.

30 STC 6/1981, FJ 4. ${ }^{\circ}$. 
Posteriormente, el Tribunal matizó su interpretación en la STC 6/1988, FJ 4. ${ }^{\circ}$, que inicia una consolidada línea doctrinal. En el artículo 20.1 se reconocen dos derechos de contenido próximo, pero no idéntico. La libertad de expresión en sentido estricto, que consiste en expresar y difundir libremente pensamientos, ideas y opiniones mediante la palabra el escrito o cualquier otro medio de reproducción (apartado a). Y el derecho a comunicar o recibir libremente información veraz por cualquier medio de difusión (apartado d) ${ }^{31}$.

La diferencia fundamental entre ambos derechos reside en el objeto. La libertad de expresión, en sentido estricto, transmite pensamientos, ideas y opiniones, diversas y subjetivas; en cambio, el derecho a la información relata hechos, conductas, noticias, que son concretas y objetivas ${ }^{32}$.

El profesor Solozábal Echavarría recuerda otras dos importantes diferencias, remarcadas por la doctrina alemana y que son aplicables a nuestro ordenamiento $^{33}$. La libertad de expresión, en sentido estricto, protege exclusivamente una sola actividad: la comunicación sin trabas del pensamiento. En cambio, el derecho a la información garantiza múltiples actividades, como la preparación, elaboración, selección y difusión de la información ${ }^{34}$.

31 La STC 105/1983, FJ $11^{\circ}$, de 23 de noviembre, fue la primera en afirmar que el apartado d) del artículo 20.1 consagraba un derecho diverso del a). No obstante, se trata de un pronunciamiento aislado que no siguen las sentencias posteriores y, además, no acaba de delimitar correctamente el objeto del nuevo derecho.Por la razón expresada hay que esperar a la STC 6/88, de 21 de enero, FJ 5. ${ }^{\circ}$, donde tras señalar que los apartados a) y d) están separados, presentan un diferente contenido y tienen distintos límites y efectos, tanto ad extra como ad intra, señala: «En el artículo 20 de la Constitución la libertad de expresión tiene por objeto pensamientos, ideas, y opiniones, concepto amplio dentro del que deben incluirse también las creencias y los juicios de valor. El derecho a comunicar y recibir libremente información versa en cambio, sobre hechos..... Para más adelante precisar: "La comunicación que la Constitución protege es [...] la que transmita información veraz". Posteriormente, la línea doctrinal se consolida; entre otras, las SSTC 107/1988, FJ 2. ${ }^{\circ}$, de 8 de junio; 51/1989, FJ 2..$^{\circ}$, de 22 de febrero; 4/1996, FJ 3. ${ }^{\circ}$, de 16 de enero; 51/1997, FJ 4..$^{\circ}$, de 11 de marzo. SOLOZÁBAL ECHAVARRÍA, Juan José, "Libertad de expresión, información y relaciones laborales (Comentario a la sentencia del Tribunal Constitucional 6/1988, de 21 de enero, caso señor Crespo, asunto filtraciones al País)", Revista Española de Derecho Constitucional, núm. 26, 1989, p. 172, señala que esta sentencia reconoce el derecho a la información como autónomo respecto al apartado a) del mismo artículo. Esto implica otorgarle una naturaleza diferente, con ámbitos, efectos y límites distintos. En contra, SANTAOLALLA LÓPEZ, Fernando, "Jurisprudencia del Tribunal Constitucional...", ob. cit., p. 189. Sobre esta problemática véase CARMONA SALGADO, Concepción, Libertad de expresión e información y sus límites, Edersa, Madrid, 1991, pp. 7-14.

32 STC 105/1990, FJ 4. ${ }^{\circ}$, de 6 de junio; 123/1993, FJ 3. ${ }^{\circ}$, de 19 de abril, y las citadas en la nota anterior, entre otras. SOLOZÁBAL ECHAVARRÍA, Juan José, "La libertad de expresión desde la teoría...", ob. cit., p. 81; y "Acerca de la doctrina del Tribunal Constitucional...", ob. cit., p. 244. DE CARRERAS, Francesc, "La libertad de expresión...", ob. cit., p. 11. SÁNCHEZ FERRIZ, Remedio, "El derecho a la información en la jurisprudencia del Tribunal Constitucional", en el libro, El derecho a la información: teoría y práctica, Libros Pórtico, Zaragoza, 1995, pp. 57-58.

33 SOLOZÁBAL ECHAVARRÍA, Juan José, "Libertad de expresión, información y relaciones laborales", ob. cit., p. 173.

34 Sin una formulación tan clara, la STC 171/1990, FJ 9. ${ }^{\circ}$, de 12 de noviembre, señala: «El derecho fundamental reconocido en el art. $20 \mathrm{CE}$, no puede restringirse a la comunicación objetiva y aséptica de hechos, sino que incluye también la investigación de la causación de hechos, la formulación de hipótesis posibles en relación con esa causación, la valoración probabilística de esas hipótesis y la formulación de conjeturas sobre esa posible causación". 
Por último, el derecho a la información se singulariza respecto a la libertad de expresión por tener un mayor plus institucional, lo que explica que el primero prevalezca, en determinadas ocasiones, sobre la segunda. Esto sucede en los supuestos de réplica o rectificación ${ }^{35}$, cuando el derecho a rendir información del aludido y del público a conocer una versión plural respecto a los hechos que fueron objeto de la crónica se impone sobre la libertad de expresión negativa del medio a no contar lo que no quiere, el contenido de la rectificación.

Ambas vertientes de la libertad de comunicación no están separadas de una forma absoluta, la información no siempre es exclusivamente objetiva, puede ir acompañada de alguna valoración ${ }^{36}$ y lo mismo sucede a la inversa. No obstante, el predominio del aspecto objetivo o subjetivo en el mensaje determinará que nos encontremos en presencia del derecho reconocido en el apartado a) o en el d). La STC 6/1988 inaugura una consolidada doctrina y en su FJ 5. ${ }^{\circ}$ lo aclara con precisión: «Es cierto que, en los casos reales que la vida ofrece, no siempre es fácil separar la expresión de pensamientos, ideas y opiniones de la estricta comunicación informativa, pues la expresión de pensamientos necesita a menudo apoyarse en la narración de hechos y, a la inversa, la comunicación de hechos o noticias no se da nunca en un estado químicamente puro y comprende, casi siempre, algún elemento valorativo o, dicho de otro modo, una vocación a la formación de una opinión. Ello aconseja, en los supuestos en que pueden aparecer entremezclados elementos de una y otra significación, atender, para calificar tales supuestos y encajarlos en cada uno de los apartados del art. 20, al elemento que en ellos aparece como preponderanten.....el que alguna de las manifestaciones vertidas en torno a tales hechos entrañaran algún juicio de valor o alguna dosis de crítica no es suficiente para relativizar el carácter preponderante del elemento informativo, ${ }^{37}$.

35 Véase CARRILLO, Marc, "Libertad de expresión y derecho de rectificación en la Constitución española", Revista de Derecho Político, núm. 23, 1986; y BOUZAT, G., "Libertad de expresión y estructura social: el derecho de réplica", Revista del Centro de Estudios Constitucionales, núm. 3, 1989. Una síntesis de la jurisprudencia constitucional sobre el derecho de rectificación en la STC 51/2007, FJ 8. , de 12 de marzo.

36 SOLOZÁBAL ECHAVARRÍA, Juan José, "Aspectos constitucionales de la libertad de expresión...", ob. cit., p. 144, señala: "Tampoco cabe aceptar que el derecho a la comunicación de información abarque exclusivamente las noticias y no las opiniones o juicios de valor. La distinción entre hecho y actitud valorativa es imposible de verificar en muchos casos. Ciertamente no hay juicios de valor sin referencia a los hechos; y la información su selección, elaboración y presentación, sin el filtro categorial, subjetivo y cuajado de posiciones personales, del informante es imposible". FERNÁNDEZ MIRANDA CAMPOAMOR, Alfonso, "Libertad de expresión y derecho de la información", en la obra Constitución Española de 1978, tomo II, Comentarios a las Leyes Políticas, dirigidos por ALZAGA VILLAAMIL, Oscar, Edersa, Madrid, 1984, p. 531, considera que la simple selección de hechos y la forma de presentarlos no deja de expresar en la mayor parte de los casos apreciaciones y preferencias subjetivas que comportan una particular valoración, con lo que la frontera entre noticia y opinión deja frecuentemente de estar claramente definida". En el mismo sentido CARRILLO, Marc, "Derecho a la información y veracidad informativa (Comentario a las SSTC 186/86 y 6/88), Revista Española de Derecho Constitucional núm. 23, 1988, p. 190.

37 En la misma línea las SSTC 105/1990, FJ 4. ${ }^{\circ}$, de 6 de junio,;171/1990, FJ $10 .^{\circ}$, de 12 de noviembre; 172/1990, FJ $3 .^{\circ}$, de 12 de noviembre; 123/1993, FJ $3 .{ }^{\circ}$, de 19 de abril; $136 / 1994$, FJ $1 .^{\circ}$, de 9 de mayo; 76/1995, FJ 2. ${ }^{\circ}$, de 22 de mayo; 4/1996, FJ 3. ${ }^{\circ}$, de 16 de enero; más recientemen- 


\section{OTRAS DIFERENCIAS}

Ambas libertades se distinguen, además, porque la libertad de información es un presupuesto de la libertad de expresión en sentido estricto. La veracidad es una exigencia intrínseca, pero sólo para la tutela de la libertad de información. Y, finalmente, porque las reglas que permiten comprender sus restricciones son diversas.

La libertad de información como presupuesto de la libertad de expresión en sentido estricto

La libertad de información consiste, precisamente, en el derecho a informarse. Pero, por otra parte, este derecho de libertad es el presupuesto para la formación de la opinión que precede a la expresión de ésta ${ }^{38}$. Pues sólo una información completa hace posible la libre formación y expresión de la opinión, tanto para el individuo como para la sociedad.

\section{La veracidad una exigencia intrínseca a la libertad de información}

La libertad de información debe cumplir con la exigencia de veracidad para disfrutar de la tutela constitucional. En cambio, este requisito no es exigible a la libertad de expresión en sentido estricto, dada su naturaleza eminentemente subjetiva. Por veracidad cabría entender una correspondencia en-

te, 181/2006, FJ 4. ${ }^{\circ}$, de 19 de junio; y 139/2007, FJ 6. ${ }^{\circ}$, de 4 de junio, entre otras. SOLOZÁBAL ECHAVARRÍA, Juan José, "Libertad de expresión, información y relaciones laborales...”, ob. cit., pp. 173-174, propone también esta solución; así como recurrir a la diferenciación que hace la doctrina americana entre las opiniones que contienen información y las que son puramente deductivas o evaluativas, fórmula recordada en España por MUÑOZ MACHADO, Santiago, Libertad de prensa y procesos por difamación, Ariel, Barcelona, 1988, pp. 112 y ss.

38 SOLOZÁBAL ECHAVARRÍA, Juan José, "La libertad de expresión desde la teoría...", ob. cit., p. 81, considera aplicable a nuestro ordenamiento constitucional la siguiente afirmación del Tribunal Federal alemán: "La libertad de información es, precisamente, el derecho a informarse. Por otra parte, este derecho de libertad es el presupuesto de la formación de la opinión que precede a la expresión de ésta. Pues sólo una información completa posibilita la libre formación y expresión de la opinión, tanto para el individuo como para la sociedad" [(BVerfG, t. 27, p. 71 (81). Asimismo, t. 27, p. 104 (108). Véase SCHMITTGLAESSER, W., "Die Meinungsfreiheit in der Rechtsprechung des Bundesverfassungsgerichts (1. Teil), en Archiv des offentlichen rect., 97, 1972, p. 63]. En su trabajo "Libertad de expresión, información y relaciones laborales...", ob. cit., p. 173, estima que esta aplicabilidad se refuerza si se considera que la STC 159/1986 se ha expresado en semejantes términos, aunque globalizando los apartados a) y d) del artículo 20, probablemente porque no los diferenció con absoluta nitidez hasta la STC 6/1988. Como se puso de relieve en el citado seminario de la Autónoma, por el profesor José Luis Rodríguez, esta tesis no es pacífica en Alemania. No obstante, estimo que la mayor parte de nuestras opiniones, excluidas algunas de las que adquirimos por nuestras facultades cognitivas, se forman en función de los conocimientos suministrados por la libertad de información, entendida ésta en un sentido muy amplio. 
tre los hechos transmitidos y la realidad; no obstante, el máximo intérprete de la Constitución ha desobjetivado la cuestión, al considerar que de imponerse la verdad absoluta la única garantía jurídica sería el silencio.

En un primer momento, la jurisprudencia del Tribunal Constitucional, aunque refiriéndose fundamentalmente a la información periodística, consideró que la pluralidad de fuentes informativas era garantía de la veracidad de la información.

Posteriormente, convirtió la veracidad en una exigencia intrínseca para obtener la tutela constitucional, equiparó la veracidad a comportarse con una razonable diligencia profesional en la obtención de la información y admitió que las informaciones erróneas son inevitables en un debate libre.

Tras la STC 6/1988, de 21 de enero, FJ 5. ${ }^{\circ}$, la veracidad se convierte en una exigencia intrínseca, una condición requerida en cada caso, de la protección constitucional de la información, dejando de ser sólo una garantía general del pluralismo informativo ${ }^{39}$.

La exigencia de razonable diligencia profesional aparece en el mismo fundamento de la sentencia analizada, cuando se señala que se garantiza el derecho de todos a comunicar hechos y conductas veraces, esto es, vertidos con diligencia razonable, aunque puedan resultar erróneos. Al informador "se le puede y debe exigir que lo que transmita como "hechos" haya sido objeto de previo contraste con datos objetivos, privándose, así, de la garantía constitucional a quien defraudando el derecho de todos a la información, actúe con menoscabo de la veracidad o falsedad de lo comunicado".

El nivel de diligencia, que es necesario para garantizar la veracidad en la jurisprudencia constitucional, es sintetizado por la STC 190/1996, FJ 3. ${ }^{\circ}$ cuando señala: "Dicho nivel se sitúa en el amplio espacio que media entre la verificación estricta y exhaustiva de un hecho, en un extremo, y la transmisión de suposiciones, meras invenciones, insinuaciones insidiosas, o noticias gratuitas o infundadas cuando la información pueda suponer el descrédito ajeno (SSTC 6/1988, 171/1990, 139/1995), en el otro. Su precisión, que [es] la del nivel de razonabilidad en la comprobación de los hechos afirmados, viene dada por los deberes profesionales de actuación periodística (SSTC 219/92, 240/92) y dependerá en todo caso de las características concretas de la comunicación de que se trate(STC 240/1992) entre las que se ha de destacar la de si lo que se transmite por la vía o no del denominado "reportaje neutral", no es sino que otro medio o persona realiza determinadas afirmaciones (SSTC 41/1994, 6/1996, 52/1996)".

El mismo FJ 3. ${ }^{\circ}$ de la STC 190/96 añade que "Otras circunstancias, finalmente, pueden contribuir a perfilar el comportamiento debido del informador en la búsqueda de la verdad, tales como la fuente que proporciona la noticia, las posibilidades efectivas de contrastarla (STC 240/1992) y la existencia de resoluciones judiciales referidas a los hechos comunicados (STC 28/1996)". In-

39 Véase CARRILLO, Marc., "Derecho a la información y veracidad informativa", ob. cit. 
cluso, cabe que cuando la fuente que proporciona la noticia reviste características objetivas que la hacen fidedigna, seria o fiable puede no ser necesaria mayor comprobación que la exactitud o la identidad de la fuente, según indica la STC 240/92, FJ 5. ${ }^{\circ}$, entre otras.

Que las informaciones erróneas son inevitables en un debate libre ya fue señalado por la STC 6/88, FJ $5 .^{\circ}$, en donde tras insistir en que la información cubierta por la garantía constitucional es la veraz, esto es, la "información rectamente obtenida y difundida", se concluye "aunque su total exactitud sea controvertible", pues las "afirmaciones erróneas son inevitables en un debate libre, de tal forma que, de imponerse "la verdad" como condición para el reconocimiento del derecho, la única garantía de la seguridad jurídica sería el silencio" ${ }^{40}$.

Junto al criterio de la diligencia profesional, el Tribunal, al menos desde la STC 159/1986, estima que también se cumple con el criterio de la veracidad a través de la técnica del reportaje neutral trasladada de la jurisprudencia estadounidense, que consiste en reproducir asépticamente la información de un tercero que esté identificado ${ }^{41}$.

40 MUÑOZ MACHADO, Santiago, Libertad de prensa y procesos..., pp. 154 y ss. anticipó el contenido de esta sentencia

41 La reciente STC $193 / 2007$, FJ $11 .^{\circ}$, de 4 de junio, sintetiza perfectamente la doctrina constitucional sobre el reportaje neutral: «En la STC 53/2006, de 27 de febrero (FJ 8) —que, por su parte, remite a las SSTC 54/2004, de 15 de abril, FJ 7, y 76/2002, de 8 de abril, FJ 4- ha declarado este Tribunal que para que pueda hablarse de reportaje neutral han de concurrir los siguientes requisitos: aa) El objeto de la noticia ha de hallarse constituido por declaraciones que imputan hechos lesivos del honor, pero que han de ser por sí mismas, esto es, como tales declaraciones, noticia y han de ponerse en boca de personas determinadas responsables de ellas (SSTC 41/1994, de 15 de febrero, FJ 4, y 52/1996, de 26 de marzo FJ 5). De modo que se excluye el reportaje neutral cuando no se determina quién hizo tales declaraciones [STC 190/1996, de 25 de noviembre, FJ 4 b)]. "b) El medio informativo ha de ser mero transmisor de tales declaraciones, limitándose a narrarlas sin alterar la importancia que tengan en el conjunto de la noticia (STC 41/1994, de 15 de febrero, FJ 4). De modo que si se reelabora la noticia no hay reportaje neutral (STC 144/1998, de 30 de junio, FJ 5). "Y sobre esta base "cuando se reúnen ambas circunstancias la veracidad exigible se limita a la verdad objetiva de la existencia de dichas declaraciones y a la fidelidad a su contenido: si concurren ambas circunstancias el medio ha de quedar exonerado de responsabilidad. Como dijimos en la STC 76/2002, de 8 de abril, FJ 4, 'en los casos de reportaje neutral propio la veracidad exigible se limita a la verdad objetiva de la existencia de la declaración, quedando el medio exonerado de responsabilidad respecto de su contenido (STC 232/1993, de 12 de julio, FJ 3). Consecuentemente la mayor o menor proximidad al reportaje neutral propio modula la responsabilidad por el contenido de las declaraciones (SSTC 240/1992, de 21 de diciembre, FJ 7, y 144/1998, de 30 de junio, FJ 5)'; de este modo, la ausencia o el cumplimiento imperfecto de los señalados requisitos determinarán el progresivo alejamiento de su virtualidad exoneratoria". "Y en la STC 136/1999, de 20 de julio, FJ 17, afirmamos que no cabrá hablar de reportaje neutral cuando quien lo difunde no se limita a ser un mero transmisor del mensaje, es decir, a comunicar la información, sino que utiliza el mensaje, no para transmitir una noticia, sino para darle otra dimensión. Por fin, en la STC 134/1999, de 15 de julio, FJ 4, se recuerda que 'estaremos ante un reportaje neutral si el medio de comunicación se ha limitado a cumplir su función transmisora de lo dicho por otro, aunque él haya provocado esa información, siempre que no la manipule mediante su artero fraccionamiento en el seno de un reportaje de mayor extensión, interfiriendo en su discurrir con manifestaciones propias, 
Finalmente, a mi juicio, el máximo interprete constitucional, en la STC 40/1992, FFJJ $1 .^{\circ}$ y $2 .^{\circ}$, sienta las bases para que se pueda considerar que se falta también a la veracidad cuando se omite parte de la información.

Si se sintetiza la jurisprudencia constitucional, puede afirmarse que la veracidad no es propiamente un límite, sino una exigencia intrínseca para obtener la tutela del derecho. La veracidad requerirá pluralismo informativo, diligencia profesional, y que no se omita intencionadamente parte del contenido informativo. Esta doctrina jurisprudencial sobre la veracidad, aunque elaborada principalmente para los profesionales de la información, es aplicable a los demás ámbitos en que se ejerza la libertad de información.

\section{Los límites de la libertad de comunicación}

La Constitución española presupone que las libertades de comunicación constituyen un campo abonado al conflicto, como demuestra el propio artículo $20 \mathrm{CE}$, en su apartado $4 .^{\circ}$, cuando establece: "Estas libertades tienen su límite en el respeto a los derechos reconocidos en este Título, en los preceptos de las leyes que los desarrollen y, especialmente, en el derecho al honor, a la intimidad, a la propia imagen, y a la protección de la juventud y de la infancia".

Estos límites son más amplios de lo que literalmente se expresa ${ }^{42}$, pero no implican una mayor intensidad en las restricciones, sino que detallan aquellos bienes jurídicos con los que la confrontación resulta más frecuente ${ }^{43}$. Así la

componiéndolo con textos o imágenes cuyo propósito sea, precisamente, quebrar la neutralidad del medio de comunicación respecto de lo trascrito, de suerte que esa información haya dejado de tener su fuente en un tercero, para hacerla suya el medio de comunicación que la reproduce y difunde; es decir, cuando el medio, haya permanecido o no ajeno a la generación de la información, no lo fuera, y esto es lo que importa, respecto de la forma en la que lo ha transmitido al público".

Por fin, conviene recordar que en el presente asunto concurre una circunstancia muy relevante a los efectos de determinar los deberes y responsabilidades de los conductores del programa y de RTVE. Esta circunstancia consiste en el hecho de que las declaraciones de las hermanas Calero Sierra se realizaron durante una entrevista realizada en el curso de un programa de televisión emitido en hora punta, de tal forma que no puede pasarse por alto el impacto, dada la inmediatez y poder de penetración de los medios audiovisuales, que las afirmaciones realizadas pudieron llegar a poseer. La importancia de valorar este extremo cuando se trata de considerar los deberes y responsabilidades de un periodista ha sido puesta de relieve por el Tribunal Europeo de Derechos Humanos, entre otras, en su Sentencia de 23 de septiembre de 1994, dictada con motivo del asunto Jersild c. Danemark, y conduce a concluir que el deber de responsabilidad exigible a los periodistas y medios de comunicación es si cabe mayor cuando se trata de medios audiovisuales habida cuenta de que "por las imágenes los medios audiovisuales pueden transmitir mensajes que un medio escrito no es apto para trasmitir".

42 MUÑOZ MACHADO, Santiago, Libertad de prensa..., ob. cit., pp. 151-152; y DE CASADEVANTE ROMANI, Carlos Fernández, La aplicación del Convenio Europeo de Derechos Humanos en España, Tecnos, Madrid, 1988, p. 55, en el mismo sentido.

43 FERNÁNDEZ MIRANDA CAMPOAMOR, Alfonso, "Libertad de expresión y derecho de la información", ob. cit., pp. 501 y 524-525. 
STC 181/1990, FJ 3. ${ }^{\circ}$, señala: «...los derechos fundamentales, y los del artículo 20 C.E. entre ellos, no son derechos absolutos e ilimitados: por el contrario, su ejercicio está sujeto tanto a límites expresos constitucionalmente como a otros que puedan fijarse para proteger o preservar otros derechos o bienes constitucionalmente protegidos ${ }^{44}$.

Algunas reglas elementales sobre la concordancia práctica

Para analizar las reglas que presiden los conflictos entre las libertades de comunicación y otros derechos o bienes constitucionales es necesario recordar algunas nociones de teoría general. No hay una clasificación axiológica de los derechos y libertades fundamentales, por tanto no hay derechos absolutos, no hay ninguno que en abstracto prevalezca sobre los demás, todos tienen límites. Las restricciones a los derechos fundamentales surgen, preferentemente, de la necesidad de que un mismo derecho sea disfrutado simultáneamente por una pluralidad de individuos, y de los conflictos entre un derecho fundamental y un bien, valor o principio constitucional o de la confrontación entre dos derechos. El enfrentamiento, entre estos últimos, no puede resolverse afirmando la prevalencia en abstracto de uno de ellos, sino acudiendo a la regla de la ponderación o de la concordancia práctica ${ }^{45}$. Esto significa que hay que atender a las circunstancias, al caso concreto, y decidir en una situación dada cuál de los dos derechos prevalece. El dominante se impone sobre el otro, pero ambos se limitan recíprocamente, el derecho debilitado debe mantener buena parte de su contenido.

La jurisprudencia constitucional nos ha ido dando reglas de esta ponderación, sobre todo en la STC 120/1990, FJ 8. ${ }^{\circ}$, donde se sintetizan los principios de carácter general que debe cumplir cualquier limitación que se imponga a un derecho fundamental: No se puede obstruir un derecho más allá de lo razonable. Tiene que quedar asegurado que las medidas limitadoras son necesarias para conseguir el fin perseguido. Debe existir proporcionalidad entre el sacrificio del derecho y la situación en que se encuentra aquel a quien se le impone. Por último, en cualquier caso tiene que respetarse el contenido

44 La primera sentencia no incluye como límite a los bienes, sino sólo a los derechos (STC 5/1981, FJ 7. ${ }^{\circ}$, de 13 de febrero.). La STC 2/82, FJ 5. ${ }^{\circ}$, de 29 de enero, señala, por primera vez, que otros bienes constitucionalmente protegidos limitan a la libertad de comunicación. Se trata de una doctrina consolidada: SSTC 11/1981, FJ 7.', de 8 de abril; 91/1983, FJ 3..$^{\circ}$, de 7 de noviembre; 110/1984, FJ 5. ${ }^{\circ}$, de 26 de noviembre; 159/1986, FJ 5. ${ }^{\circ}$, de 12 de diciembre; 120/1990, FJ 8. ${ }^{\circ}$, de 27 de junio; 181/1990, de 15 de noviembre, entre otras.

45 STC 168/86, FJ 3. ${ }^{\circ}$, de 22 de diciembre: “...el conflicto entre ambos derechos fundamentales no puede resolverse otorgando prevalencia al proclamado en el artículo 18.1 de la Constitución, sino que se impone siempre una ponderación entre uno y otro, sin olvidar que en esa ponderación el derecho de información, junto con el de libre expresión, garantiza la existencia de una opinión pública libre». Posteriormente SSTC 156/1986, FJ 3., de 9 de diciembre; 199/1987, FJ $12 .^{\circ}$, de 16 de diciembre; 121/1989, FJ 2. ${ }^{\circ}$, de 3 de julio; 143/1991, FJ 2. ${ }^{\circ}$, de 1 de julio; 15/1993, FJ $1 .^{\circ}$, de 18 de enero; 78/1995, FJ $2 .^{\circ}$, de 22 de mayo; 204/1997, FJ $2 .^{\circ}$, de 25 de noviembre. 
esencial. Dicho en palabras del Constitucional: "Las limitaciones que se establezcan a los derechos fundamentales "no pueden obstruir el derecho más allá de lo razonable" (STC 53/86, FJ 3.'), de modo que todo acto o resolución que limite derechos fundamentales ha de asegurar que las medidas limitadoras sean necesarias para conseguir el fin perseguido (SSTC 62/82, FJ 5.; 13/85, FJ $\left.2 .^{\circ}\right)$ y han de atender a la "proporcionalidad entre el sacrificio del derecho y la situación en que se halla aquél a quien se le impone" (STC 37/89, FJ 7.') y, en todo caso, respetar su contenido esencial (SSTC 11/81, FJ 10. ${ }^{\circ}$; 196/87, FJ 4. ${ }^{\circ}$, $5 .^{\circ}$ y $6 .^{\circ}$; y $197 / 87$, FJ $11 .^{\circ}$ ) si tal derecho aún puede ejercerse".

Cuando el conflicto es entre un derecho y otro bien constitucional se debe tener muy presente lo señalado en la STC 159/1986, FJ 6. ${ }^{\circ}$, cuando el delito de apología del terrorismo trataba de restringir a la libertad de información: "...la fuerza expansiva de todo derecho fundamental restringe, por su parte, el alcance de las normas limitadoras que actúan sobre el mismo; de ahí la exigencia de que los límites de los derechos fundamentales hayan de ser interpretados con criterios restrictivos y en el sentido más favorable, a la eficacia y a la esencia de tales derechos ${ }^{46}$.

Algunas reglas específicas de ponderación cuando está implicada la libertad de comunicación

Tengo la impresión que la contradicción entre dos grandes bloques de sentencias constitucionales a propósito de la titularidad del derecho a la libertad de comunicación, en realidad puede resolverse estimando que cuando una comunicación se emite por la prensa se presupone que versa sobre hechos noticiables, relevantes para formar una opinión pública libre, y, por tanto, se dota a los apartados a) y d) del artículo 20.1 CE de su máxima intensidad a la hora de realizar una concordancia práctica con otros derechos.

En efecto, aunque la STC 6/1981, FJ 4..$^{\circ}$, pronto atribuyó la titularidad del derecho a la libre comunicación a todas las personas, extremo confirmado por la STC 74/1982, FJ 3..$^{\circ}$ las siguientes sentencias sembraron numerosas dudas. Un nutrido bloque parece reservar la libertad a la prensa, como pone de manifiesto la STC 105/1983, FJ 11. ${ }^{\circ}$, con su referencia a hechos noticiables, que sean necesarios para facilitar la participación real de los ciudadanos, y considerar como sujetos a la colectividad y a los periodistas. La STC 168/1986, FJ $2 .^{\circ}$, restringe el objeto a los medios de comunicación, entendidos como prensa escrita, radio y televisión. La STC 165/1987, FJ 10. ${ }^{\circ}$, pese a afirmar con claridad que esta libertad no se limita a los profesionales, sino que de la misma disfrutan todos, añade que el carácter preferente de esta libertad es predicable sólo de los medios de comunicación social y, por tanto, se le niega a una hoja

46 Posteriormente, en el mismo sentido SSTC 51/1989, FJ 2. ${ }^{\circ}$, de 22 de febrero; 20/1990, FJ $4 .^{\circ}$, de 15 de febrero; 136/1994, FJ $2 .^{\circ}$, de 9 de mayo; 42/1995, FJ $2 .^{\circ}$, de 13 de febrero. 
informativa de una asociación. Por el contrario, otras sentencias, por los supuestos que analizan, parecen dejar delimitado el objeto y otorgan la titularidad a todas las personas. Así, la STC 126/1990, FFJ 3. ${ }^{\circ}, 4 .^{\circ}$ y $5 .^{\circ}$, reconoce que informar en una asamblea de trabajadores de que un representante de los mismos va a pedirse un permiso durante una huelga es una comunicación amparable por la libertad de información, veraz y con relevancia pública para los demás trabajadores. La STC 197/1988 afirma que las declaraciones como testigo en un proceso están amparadas por la libertad de información: «El bien jurídico tutelado por este derecho constitucional no desaparece por el mero hecho de que la comunicación se produzca ante el Juez y en el contexto de un proceso o actuación judicial" (FJ 3. ${ }^{\circ}$ ).

Estas dos líneas doctrinales contradictorias pueden armonizarse si se piensa en lo que en realidad quiere decir el Tribunal. La STC 105/1990, FJ 4. ${ }^{\circ}$, alineada con la primera posición doctrinal, permite obtener pautas para aclarar la cuestión cuando niega que la protección constitucional se limite a la prensa, pero afirma que ésta tiene una mayor garantía cuando se ejercita este derecho: «la protección constitucional de los derechos de que se trata 'alcanza un máximo nivel cuando la libertad es ejercitada por los profesionales de la información a través del vehículo institucionalizado de formación de la opinión pública que es la prensa; entendida en su acepción más amplia. Los cauces por los que se difunde la información aparecen así relevantes para determinar su protección constitucional". Finalmente la STC 132/1995, FJ 4. ${ }^{\circ}$, completa las pautas para lograr la armonización aquí pretendida, pues, de su lectura, creo interpretar que cuando se exige que el objeto verse sobre hechos noticiables, el sentido del término es que haya trascendencia para la formación de la opinión pública libre, a efectos de dotar al apartado d) de su máxima intensidad y convertirlo así en prevalente para realizar la concordancia práctica con el derecho al honor - éste era el objeto de la sentencia, pero nada impide extender la regla a los conflictos con otros bienes constitucionales-.

Frente a lo afirmado literalmente por numerosas sentencias, la libertad de información no se limita a los periodistas, a los medios de comunicación —en concreto, prensa escrita, radio y televisión - ni a mensajes que contengan hechos noticiables; ni siquiera en estos casos se fortalece la protección constitucional del $20.1 \mathrm{~d}$ ). Todas las comunicaciones veraces tienen la misma protección constitucional, el objeto del derecho es indeterminado; otra cosa serán los límites, tal y como ya se ha señalado en anteriores apartados. Lo que en realidad quiere decir el Tribunal, en mi opinión, es que cuando la libertad de información entra en conflicto con otro derecho o bien constitucional, ésta se refuerza en estos supuestos y convierte en preponderante al $20.1 \mathrm{~d}$ ) a la hora de realizar la correspondiente concordancia práctica. Por tanto, considero que cuando hay un conflicto de derechos hay elementos que permiten presumir o presuponer que la libertad de comunicación será el derecho preponderante en caso de confrontación. Estos elementos son que el mensaje sea emitido por un periodista, que se realice a través de un medio de comunicación social, que la materia del mensaje sea relevante para formar la opinión 
pública libre, entre otros. Con este entendimiento, aquí defendido, se logra armonizar la aparente contradicción de estas dos posiciones jurisprudenciales.

La veracidad de la información ya se ha visto que es una exigencia intrínseca para obtener la tutela constitucional. Este requisito se cumple con un grado razonable de diligencia profesional, pero creo que ésta se incrementa en caso de confrontación con otro derecho. En efecto la STC 190/1996, FJ 3. ${ }^{\circ}$, tras sintetizar el nivel ordinario de diligencia profesional que es necesario para garantizar la veracidad, establece: "El nivel de diligencia exigible adquirirá "su máxima intensidad", en primer lugar, "cuando la noticia que se divulga puede suponer por su propio contenido un descrédito en la consideración de la persona a la que la información se refiere (SSTC 240/1992, 178/1993), criterio al que se suma también, de modo bifronte el de la "trascendencia de la información", pues, si bien ésta sugiere de suyo un mayor cuidado en la contrastación (así, SSTC 219/1992, 240/1992), apunta también a la mayor utilización social de una menor angostura en la fluidez de la noticia (STC 28/1996) " ${ }^{47}$.

Las dos reglas anteriores son importantes a la hora de realizar una concordancia práctica en que esté implicada la libertad de comunicación ${ }^{48}$. No obstante, la STC 107/1988, FJ 2. ${ }^{\circ}$, aporta, con absoluta precisión, otras dos aún más relevantes.

En primer lugar, es clave que nos encontremos ante la libertad de información del apartado d) o ante la libertad de expresión en sentido estricto del apartado a), las limitaciones serán muy distintas en uno y otro caso. En este campo la mayor dificultad se encuentra en el hecho de que la información se suele acompañar de opiniones y viceversa. La solución, tal y como ya señalamos, consiste en determinar la vertiente predominante en el mensaje.

En segundo lugar, es fundamental la materia a la que se refiera la comunicación. Se debe diferenciar entre asuntos de relieve público y aquéllos que son meramente privados, lo que puede suceder por la condición del sujeto de la comunicación o por la materia objeto de la discusión. La distinción tiene una importancia capital; porque, cuando el conocimiento del contenido del mensaje sea necesario por su interés público, en caso de conflicto, la vertiente institucional de la libertad de comunicación convierte en preponderante este derecho. "Por el contrario, la eficacia justificadora de dichas libertades pierde su razón de ser en el supuesto de que se ejerciten en relación con conductas privadas carentes de interés público y cuya difusión y enjuiciamiento públicos son innecesarios, por tanto, para la formación de la opinión pública libre en atención a la cual se les reconoce su posición prevalente, ${ }^{49}$.

47 La STC 139/2007, FJ 9. ${ }^{\circ}$, de 4 de junio, en el mismo sentido.

48 Véase SÁNCHEZ FERRIZ, Remedio, Delimitación de las libertades informativas (Fijación de criterios para la resolución de conflictos en sede jurisdiccional), Tirant Lo Blanch, Valencia, 2004.

49 La STC 107/1988, FJ 2. ${ }^{\circ}$, de 8 de julio, construye la línea jurisprudencial reflejada en el texto y consolidada por las sentencias posteriores: SSTC 51/1989, FJ 2. ${ }^{\circ}$, de 22 de febrero;. 105/1990, FJ $4 .^{\circ}$, de 6 de junio; $171 / 1990$, FJ $5 .^{\circ}$ y $10 .^{\circ}$, de 12 de noviembre; $172 / 1990$, FJ $2 .^{\circ}, 3 .^{\circ}$ y $4 .^{\circ}$ (donde en referencia a un sujeto privado se diferencia la información necesaria para formar opinión pública amparada constitucionalmente y la que no tiene este carácter y constituye por tanto una 
Conflictos con el derecho al honor, a la intimidad y a la propia imagen

El conflicto fundamental es entre la libertad de información y el derecho a la intimidad ${ }^{50}$, pues sus consecuencias son análogas mutatis mutandis a las que se producen cuando la primera libertad, la de información, entra en confrontación con el honor o la propia imagen, aunque alguna precisión menor se realizará al final de este apartado. También, al cierre de éste, se introducirán las matizaciones necesarias a propósito de la confrontación entre la libertad de expresión, en sentido estricto, y el derecho al honor ${ }^{51}$; porque el conflicto entre ésta y la intimidad es prácticamente inexistente, como a continuación se va a examinar.

La confrontación entre la libertad de expresión, en sentido estricto, y el derecho a la intimidad se dará en contadas ocasiones y se resolverá de forma muy parecida a cuando este último derecho entre en conflicto con la libertad de información. Y esto se justifica porque la información, entendida como conocimiento, es el presupuesto de la libertad de expresión; es decir, la primera es condición de la segunda, ésta no puede ejercitarse sin aquél, sin información no puede haber opinión. Esta afirmación requiere una matización; es cierto que la mayor parte de los conocimientos nos vienen dados a través de alguna forma de libertad de comunicación, entendida en sentido amplio, aunque otros no, pero esto último, en lo que aquí interesa, no obsta para lo reseñado. Las conclusiones extraídas decaerán sólo en aquellos casos en que una intromisión en la privacidad se divulgue públicamente no como información, sino como opinión; aunque en este caso aparecerán entremezcladas; esto es, para opinar sobre el ámbito privado de un sujeto se habrá tenido que dar en el mismo mensaje información sobre la intromisión. Esta única excepción implica que en un hipotético conflicto entre intimidad y libertad de expresión la confrontación se resuelve en los mismos términos que cuando el enfrentamiento es con la libertad de información, con las siguientes modificaciones: la información presupuesto de la opinión debe ser veraz; y la opinión, preponderante en este mensaje, tiene como límite insuperable el insulto y la expresión gravemente injuriosa o vejatoria. No obstante, la STC 232/93, FJ 1. ${ }^{\circ}$, parece señalar que cuando la confrontación es con el derecho a la intimidad y en un mensaje aparecen entremezcladas opiniones e informaciones, para saber ante qué libertad nos encontramos, no hay que atender al elemento preponderante, sino que directamente estamos ante la libertad de información. Por todo ello, se puede concluir que el conflicto entre derecho a la

vulneración de su intimidad), de 12 de noviembre; 232/1992, FJ 4. ${ }^{\circ}$, de 12 de julio; 15/1993, FJ 2. ${ }^{\circ}$, de 18 de enero; 132/1995, FJ $4 .^{\circ}$, de 11 de septiembre.

50 Véase MEDINA GUERRERO, Manuel, La protección constitucional de la intimidad, frente a los medios de comunicación, Valencia, Tirant Lo Blanch, 2005.

51 Sobre la jurisprudencia de estos derechos, véase PARDO FALCÓN, J., “Los derechos del artículo 18 de la Constitución Española en la jurisprudencia del Tribunal Constitucional", Revista Española de Derecho Constitucional, núm. 34, 1992. 
intimidad y libertad de expresión, en sentido estricto, es casi inexistente, y, según esta posición, se produciría sólo cuando alguien opine sobre una información dada por otro, que viole la intimidad.

Sin olvidar las reglas generales que nos ayudan a resolver los conflictos entre derechos y las circunstancias específicas del caso concreto, hay que destacar que para resolver la confrontación entre la libertad de información y la intimidad personal ${ }^{2}$ será esencial, como se ha señalado, saber si el mensaje es un asunto de relieve público o materia meramente privada, si se está ante political speech o no; conocer cuándo se está ante un caso u otro puede venir determinado por la condición de los sujetos o por la naturaleza del objeto de la discusión. La distinción resulta capital a la hora de realizar la ponderación, porque en los casos de relieve público, la libertad de información prevalecerá sobre el derecho a la intimidad personal, como afirma expresa y reiteradamente la jurisprudencia.

Así, la STC 107/1988, FJ 2. ${ }^{\circ}$, señala que los titulares de las funciones públicas o implicados en asuntos de relevancia pública "están obligados, por ello, a soportar un cierto riesgo de que sus derechos subjetivos de la personalidad resulten afectados por opiniones o informaciones de interés general, pues así lo requieren el pluralismo político, la tolerancia y la exposición de apertura, sin los cuales no existe sociedad democrática”. Y la STC 105/1990, FJ 4. ${ }^{\circ}$, afirma que la protección constitucional de la libertad de información se reduce si ésta "no se refiere a personalidades públicas que, al haber optado libremente por tal condición, deben soportar un cierto riesgo de una lesión de sus derechos de la personalidad, por lo que en correspondencia, se debilitaría la eficacia de tal protección en los supuestos de información u opinión sobre conductas privadas carentes de interés público".

Esta doctrina se comparte sustancialmente. No obstante, en mi opinión, la fundamentación no es adecuada; como tampoco lo es, en la jurisprudencia constitucional, la caracterización de interés general, relieve público o political speech, donde reina cierta confusión. A continuación, se examinarán ambos extremos dada la importancia que revisten a la hora de realizar la ponderación entre estos derechos.

Como se ha reseñado al examinar la naturaleza jurídica de la libertad de comunicación, el Tribunal Constitucional, al igual que la mayor parte de la literatura jurídica, fundamenta la prevalencia de la libertad de información atribuyéndole una vertiente institucional, que extrae de las teorías que justifican la libertad de expresión en sentido amplio, yo creo que éste no es el camino.

Tres son las teorías que han justificado históricamente la libertad de expresión, en sentido amplio: el debate libre conduce a la verdad; la dignidad de la persona y el libre desarrollo de su personalidad; y la imprescindibili-

52 Véase SANTAMARÍA PASTOR, J.A., "Sobre el derecho a la intimidad, secretos y otras cuestiones innombrables", Revista Española de Derecho Constitucional, núm 15, 1985; y RUIZ MIGUEL, C., La configuración constitucional del derecho a la intimidad, Tecnos, Madrid, 1994, especialmente, pp. 226-262. 
dad de la libertad de expresión para el funcionamiento del sistema democrático. La segunda teoría predominaba en Europa, la tercera en Estados Unidos, la primera ha incluido sus argumentos en las dos anteriores. No obstante, en las últimas décadas llega a Alemania y España la influencia estadounidense.

Un sector doctrinal afirma que la libertad de comunicación es una garantía institucional ${ }^{33}$, un derecho político ${ }^{54}$, lo que quiere decir que su justificación descansa en su imprescindibilidad para el funcionamiento del sistema democrático, en definitiva, permitir que se cree una opinión pública libre. Las consecuencias de esta tesis son, en lo que aquí interesa, que cuando el afectado por el mensaje o éste mismo se refieran a materia política prevalecerá de forma absoluta sobre la intimidad personal. En el resto de mensajes dominará el derecho a la intimidad personal, pues la libertad de comunicación sólo tutela la materia política por ser imprescindible para el sistema democrático.

El otro sector doctrinal, acompañado de los Tribunales Constitucionales español y alemán, llega a unas consecuencias más acertadas. La libertad de comunicación es un derecho libertad que se justifica por la dignidad personal y el libre desarrollo de la personalidad; pero tiene una vertiente institucional. Observen en una teoría garantía institucional, en otra vertiente institucional. Por ello, también aquí prevalece la libertad de información sobre el derecho a la intimidad personal, cuando el mensaje es político. No hay predominio de la información, o no hay reglas especiales cuando el mensaje se refiera a cualquier otra materia no política.

Creo que es necesario matizar ambas tesis, aunque estoy más cercano a la última. Como ya se ha señalado, la libertad de comunicación se justifica en la dignidad de la persona ${ }^{55}$, no sólo por nuestra tradición histórica, sino porque así lo afirma nuestra Constitución cuando señala que la dignidad de la persona y el libre desarrollo de la personalidad son el fundamento del or-

53 SOLOZÁBAL ECHAVARRÍA, Juan José, "La libertad de expresión desde la teoría...", ob. cit., pp. 101-111, explica claramente la concepción institucional de los derechos a una comunicación libre. RIDDER, H., "Meinungsfreiheit", en BETTERMAN, NIPPERDEY, SCHEUNER, Die Grundrechte, vol. II, 2. ${ }^{\circ}$ ed., 1968 , es su máximo defensor, pero no pueden olvidarse los trabajos de SCHNEIDER, F., Presse und Meinungsfreiheit nach dem Grundgesetz, Munich, 1952; SCHEUNER, U., "Pressefreiheit” (Bericht), en VVDStRL H., 22, 1965; y LERCHE, P., Verfassungsrechtliche Aspekte der "inneren Pressefreiheit", Berlín, 1974.Esta posición ha sido especialmente criticada: DAGTOGLOU, P., Wesen und Grenzen der Pressefreiheit, Stuttgart, 1963, pp. 30-31; CZAJKA, D., Pressefreiheit und "öffentliche Aufgabe" der Presse, Stuttgart, 1968, pp. 101 y ss.; y W. SCHMITTGLAESSER, "Die Meinungsfreiheit in der Rechtsprechung des Bundesverfassungsgerichts" (1 Teil), en Archiv des öffentlichen Recht, 97, 1972, pp. 97 y ss.

54 SÁNCHEZ GONZÁLEZ, Santiago, La libertad de expresión, Marcial Pons, Madrid, 1992, pp. 115-116, llega a señalar, en mi opinión erróneamente: «La libertad de expresión es una libertad política, que significa la ausencia de impedimentos provenientes del Estado u otro poder político organizado que hagan imposible, disuadan u obstaculicen en algún modo la crítica del poder y de los gobernantes [...] es la libertad política por excelencia".

55 Véase supra el apartado III.1., pp. 363 y ss. 
den político y de la paz social. Este dato adquiere mayor relieve si consideramos la sedes materiae del precepto, el constituyente realiza esta proclamación en el artículo 10, que abre el título de los derechos y libertades fundamentales, lo que significa que éstos encuentran en los referidos valores su justificación.

Quiere esto decir, ¿que la libertad de información sobre materia política no prevalece sobre la intimidad personal? No, en absoluto, pero la justificación es distinta, así como sus consecuencias.

Los mensajes emitidos bajo la cobertura de la libertad de comunicación se refieren a ámbitos materiales y persiguen finalidades muy diversas y, por tanto, originan diferentes conexiones sistemáticas constitucionales. Serán precisamente éstas, las que nos den las pautas para realizar la concordancia práctica entre la libertad de información y la intimidad personal.

Cuando un mensaje es de naturaleza política, la dimensión individual del derecho, su vinculación con la dignidad de la persona, se refuerza el entrar en contacto con el valor pluralismo político ${ }^{56}$, con el derecho a la participación política y, en suma, con el principio democrático, y como éstos requieren de una opinión pública libre, la libertad de comunicación se refuerza a niveles exorbitantes y prevalece sobre la intimidad personal.

Cuando un mensaje es publicitario, la libertad de comunicación entra en conexión con el derecho a la libertad de empresa, esta vinculación refuerza y debilita, a la vez, al artículo 20, pero en este caso, si hay conflicto, prevalecerá normalmente la intimidad. En cambio, la propia imagen del artículo 18 también entra en conexión con la libertad de empresa, sin embargo, aquí el lazo únicamente fortalece, no debilita; por ello, la propia imagen prevalece sobre la libertad de información publicitaria. Incluso, hasta el punto que sólo podrá utilizarse publicitariamente aquélla mediante un pago económico.

En definitiva, el contenido material de los mensajes y su finalidad pondrá en relación el artículo 20 con otros preceptos constitucionales y estas conexiones sistemáticas nos darán una importante pauta para ponderar los derechos en conflicto y tratar de determinar el prevalente en cada caso concreto; así como, en directa relación, estas conexiones, permitirán explicar las muy diferentes restricciones, en intensidad y grado, que tienen los mensajes, según a que materia se refieran ${ }^{57}$ : política, económica, publicitaria, erótica, pornográfica.

Se acaba de hablar de una pauta, pero hay otra muy importante. Concretamente, una adecuada caracterización de los conceptos interés general, political speech o relieve público; donde se ha dicho que reina una gran con-

56 Las SSTC 121/1989, de 3 de julio, FJ 2. ${ }^{\circ}$; y 107/1988, FJ 2. ${ }^{\circ}$, de 8 de junio, llegan a afirmar que la libertad de expresión tiene un valor superior o eficacia irradiante, al estar ligada al pluralismo político.

57 No muy lejana a esta creencia son las palabras de SCHIFFRIN, Steve, "Defamatory Nonmedia Speech and First Amendment Methodology", UCLA Law Review, núm. 25, 1978, p. 961, cuando señala: "la sabiduría de la jurisprudencia de la Primera Enmienda es reconocer que los intereses promovidos por la misma son numerosos y que las limitaciones gubernamentales de la expresión repercuten en esos intereses de maneras distintas". 
fusión ${ }^{58}$. Estos conceptos no pueden limitarse a conectar sistemáticamente a la libertad de información con el principio democrático y concluir que el mensaje político, por su contenido o por los participantes, convierte en derecho prevalente a la libertad de información. Ésta, según cuál sea su ámbito material y finalidad, entra en relación con otros preceptos constitucionales y si la conexión sistemática no nos aclara el derecho dominante, a lo mejor, el resultado de la ecuación sí se despeja mediante una correcta caracterización del concepto interés general, relevancia pública o political speech. En las modernas sociedades hay muchas materias, algunas políticas y otras que no lo son, que tienen interés general y relevancia pública para la sociedad; esto es, hay numerosos asuntos, sean políticos o no, cuyo conocimiento por la comunidad es necesario para que ésta se forme una opinión al respecto. Estos asuntos, que podríamos definir como públicos, que no populares, pueden en ocasiones marcar una pauta para encontrar el derecho preponderante en caso de conflicto. La jurisprudencia constitucional en la STC 139/2007, FJ 8. ${ }^{\circ}$, de 4 de junio, nos recuerda que ha considerado acontecimientos públicos [noticiables] «los sucesos de relevancia penal (STC 320/1994, de 28 de noviembre, FJ 3), y ello con independencia del carácter de sujeto privado de la persona afectada por la noticia (STC 320/1994, de 28 de noviembre FJ 4), apreciándose, asimismo, que la relevancia pública de los hechos ha de ser también reconocida respecto de los que hayan alcanzado notoriedad (STC 154/1999, de 14 de septiembre, FJ 4).

Ciertos ejemplos aclaran estas afirmaciones. Publicar que un diputado, que defiende la prohibición de la prostitución, utiliza sus servicios, supone el mismo ataque a la intimidad que si el sujeto es un cantante famoso, que no tiene una opinión formada al respecto. Sin embargo, al realizar la concordancia práctica de ambos derechos, los resultados no serán los mismos. La intromisión en la intimidad del político es obligada, en la del cantante debería ser inadmisible, ya que normalmente no se trata de una información que deba ser conocida por la sociedad para formarse una opinión al respecto. A este resultado se llega, si se considera que la existencia de un debate sobre la prohibición de la prostitución es materia política y conecta la libertad de información con el principio democrático. El sacrificio de la intimidad del diputado no surge por el sujeto, por su condición de político; sino por la materia, al pretenderse la prohibición el debate se ha convertido en político. El interés general y la relevancia de su vida privada vienen dados por su doble moral. Lo mismo sucedería con el cantante si estuviera participando activamente en el debate a favor de la prohibición y practicara también una doble moral. Vamos, a continuación, con un segundo ejemplo. El presidente de un

58 El Tribunal Supremo y la doctrina científica americana tienen problemas para diferenciar estos términos y para delimitar jurídicamente el ámbito de lo político. Véase SÁNCHEZ GONZÁLEZ, Santiago, La libertad de expresión, ob. cit., pp. 77-84. SOLOZÁBAL ECHAVARRÍA, Juan José, "Acerca de la doctrina del Tribunal Constitucional en materia de libertad de expresión", Revista de Estudios Políticos, núm. 77, 1992, p. 244, pone de relieve como en España no somos ajenos a estas dificultades. 
gran banco es una persona pública, no es un político. Informar que tiene una relación afectiva es una intromisión inaceptable en su vida privada, pero, no lo sería, si resulta que su pareja es directora de otro banco y se especula sobre la fusión entre ambas entidades financieras. Aquí, la libertad de información entra en conexión sistemática con la libertad de empresa, de donde no resulta un derecho prevalente, pero la noticia es relevante y de interés general para un sector importante de la opinión pública. Finalmente, un torero famoso, que se caracteriza por guardar celosamente su intimidad e imagen, es pasto de las tertulias televisivas respecto a su vida familiar y amorosa. Es cierto que es popular y famoso, pero no público, en el sentido que se explicaba. Su intimidad puede sufrir en lo que se relacione directamente con su actividad pública, el mundo del toreo; en todo lo demás, no parece que la libertad de información pueda restringir su intimidad, no hay interés general y relevancia pública, constitucionalmente hablando. La libertad de comunicación ampara, en cuanto derecho libertad, el cotilleo; pero, si hay confrontación con otro u otros derechos constitucionales, no parece que el derecho a una libre comunicación pueda ser el preponderante.

Nuestro más alto Tribunal parece acoger la ultima posición aquí defendida en la STC 171/1991, FJ 4. ${ }^{\circ}$, al concluir que no basta con ser famoso o popular para ver restringido el derecho a la intimidad: "La información publicada $[\ldots]$, no constituyó materia de interés general, que contribuya a la formación de la opinión pública, ni se refiere a hechos relacionados con la actividad pública de la personalidad pública, ni estaba justificada en función del interés público del asunto sobre el que se informaba.. Posteriormente, la STC 197/1991, de 17 de octubre, FJ $4^{\circ}{ }^{\circ}$, confirma que los hechos de una persona pública pueden no tener relevancia pública, y si, además, no guardan relación con la actividad que le proporciona notoriedad, su comunicación no goza de tutela constitucional. Por último, la STC $83 / 2002$, FJ $5 .^{\circ}$, recuerda que como declaro en la STC $115 / 2000$, FJ $5^{\circ}{ }^{\circ}$, «...si bien los personajes con notoriedad pública inevitablemente ven reducida su esfera de intimidad, no es menos cierto que, más allá de ese ámbito abierto al conocimiento de los demás su intimidad permanece y, por tanto, el derecho constitucional que la protege no se ve minorado en el ámbito que el sujeto se ha reservado y su eficacia como límite al derecho de información es igual a la de quien carece de toda notoriedad [...] La notoriedad pública del recurrente en el ámbito de su actividad profesional, y en concreto su proyección pública en el campo de las finanzas no le priva de mantener [...] un ámbito reservado de su vida como es el que atañe a sus relaciones afectivas [...] ya que corresponde a cada persona acotar el ámbito de intimidad personal y familiar que reserva al conocimiento ajeno".

Cuando se comenzaba el estudio de la confrontación entre libertad de información y derecho a la intimidad, se señalaba que las conclusiones serían aplicables al conflicto con el honor y la propia imagen ${ }^{59}$, con alguna pequeña

59 Véase Balaguer Callejón, ML, El derecho fundamental al honor, Tecnos, Madrid, 1993; y VIDAL MARín T., El derecho al honor y su protección desde la Constitución española, Madrid, 2000. 
precisión, que es el momento de realizar. Al mismo tiempo, se indicaba que ahora se introducirían las matizaciones necesarias a propósito de la confrontación entre la libertad de expresión, en sentido estricto, y el derecho al honor.

La libertad de información y la libertad de expresión, en sentido estricto, serán los derechos preponderantes, al entrar en colisión con el honor y la propia imagen ${ }^{60}$, en función de la correspondiente conexión sistemática constitucional —que nos vendrá dada por el ámbito material y la finalidad a que se refiera la comunicación- y, si lo anterior no fuera suficiente, cuando el sujeto o la materia tengan interés general y la intromisión sea necesaria para formar la opinión pública de una sociedad moderna. Para que esta regla tenga aplicación se requiere, además, que la libertad de información cumpla con el requisito de veracidad ${ }^{61}$; por su parte, la libertad de expresión, en sentido estricto, por su propia naturaleza, no debe cumplir con la veracidad, encontrando como único límite para la aplicación de la regla el insulto o la expresión gravemente injuriosa. La STC 172/1990, FJ 3.º, señala: "También merece distinto tratamiento el requisito de la veracidad según se trate del derecho al honor o del derecho a la intimidad, Ya que, mientras la veracidad funciona, en principio, como causa legitimadora de las intromisiones en el honor, si se trata del derecho a la intimidad actúa, en principio, en sentido diverso. El criterio para determinar la legitimidad o ilegitimidad de las intromisiones en la intimidad de las personas no es el de la veracidad, sino exclusivamente el de la relevancia pública del hecho divulgado, es decir, que su comunicación a la opinión pública, aun siendo verdadera, resulte ser necesaria en función del interés público del asunto sobre el que se informe". La doctrina referida en este párrafo, en buena parte, fue construida en la STC 107/1988; la STC105/1990, contiene una perfecta síntesis; y la 132/1995, FJ 6. ${ }^{\circ}$, extiende las reglas de ponderación al derecho a la propia imagen.

Finalmente, en la confrontación entre la libertad de expresión, en sentido estricto, y el honor y la propia imagen, se ponía parte del acento en el insulto o la expresión gravemente injuriosa. En este sentido, es obligado citar la STC 105/1990, FJ 8. ${ }^{\circ}$, que diferencia entre la crítica, la reprobación y calificación de conductas emitidas en relación con una información, por duras o penosas que sean éstas que están amparadas constitucionalmente; y los exabruptos gratuitos e innecesarios, los insultos, las expresiones gravemente injuriosas que no gozan de la protección constitucional. El siguiente párrafo del fundamento puede sintetizar la diferencia: "Pues, ciertamente, una cosa es efectuar una evaluación personal, por desfavorable que sea, de una conducta (evaluación que se inserta en el derecho de libre expresión, y que es a veces difícil o imposible separación de la mera información) y otra cosa muy distinta es emitir expresiones, afirmaciones, o calificativos claramente vejatorios desvinculados de esa información, y que resultan proferidos, gratuitamente, sin

60 Sobre los conflictos entre la libertad de expresión, entendida en sentido amplio, y el honor, resulta obligada la consulta a SALVADOR CODERCH, Pablo, El mercado de las ideas, ob. cit. 61 Véase supra apartados IV.2 y IV.3.2., y p. 27. 
justificación alguna, en cuyo caso cabe que nos hallemos ante la mera descalificación, o incluso el insulto y sin la menor relación con la información de una opinión pública libre". Señalando, además: "No cabe duda de que la emisión de apelativos formalmente injuriosos en cualquier contexto, innecesarios para la labor informativa o de formación de la opinión que se realice supone un daño injustificado a la dignidad de las personas o al prestigio de las instituciones, teniendo en cuenta que la Constitución no reconoce un pretendido derecho al insulto, que sería por lo demás incompatible con la dignidad de la persona que se proclama en el art. 10.1 del Texto fundamental ${ }^{62}$. La STC 1990/1992, FJ 5. ${ }^{\circ}$, reitera la anterior doctrina, ya consolidada, y precisa que la imputación específica al Presidente del Gobierno y al Ministro del Interior de responsabilidad a título de inducción o de encubrimiento de delitos de tortura y de asesinato supera el marco de la libertad de expresión.

La protección de la infancia y la juventud

A la hora de examinar las restricciones que sufre la libertad de comunicación se deben tener muy presentes: el artículo 39.4 CE, que dispone "Los niños gozarán de la protección prevista en los acuerdos internacionales que velan por sus derechos"; en lógico desarrollo, la Convención de Derechos del Niño, de Naciones Unidas, de 20 de noviembre de 1989, ratificada por España en 199063; y, por último, la LO 1/1996, de 15 de enero, de Protección Jurídica del Menor.

Esta última ley establece, como principio general, que en su aplicación "primará el interés superior de los menores sobre cualquier otro interés legítimo que pudiera concurrir" (art. 2). Lo que constituye, a mi juicio, una importante pauta interpretativa a la hora de realizar la concordancia práctica con la libertad de comunicación.

Esta misma disposición normativa (art. 4) y la LO 1/82, de 5 de mayo de Protección Civil del Derecho al Honor, a la Intimidad Personal y Familiar y a la Propia Imagen; prohíben la difusión de información o la utilización de datos, imágenes o nombres de menores en los medios de comunicación cuando sea contrario a su interés, incluso, cuando conste el consentimiento del menor, que puede ser objeto de manipulación por sus propios representantes legales o grupos en los que se mueve.

62 Posteriormente, SSTC 336/1993, FJ 6, de 15 de noviembre; 42/1995, 2. ${ }^{\circ}$, de 13 de febrero; 76/1995, FJ 6. ${ }^{\circ}$, de 22 de mayo, y voto particular; 204/1997, FJ $2 .^{\circ}$, de 25 de noviembre.

La STC 107/1988, FJ 2. ${ }^{\circ}$, de 8 de junio, señala que las instituciones públicas o clases determinadas del estado tienen dignidad, prestigio o autoridad moral si el legislador se la otorga, pero estos valores no son subsumibles en el honor tal y como se ha constitucionalizado; por lo que su nivel de protección es más débil cuando entra en confrontación con la libertad de comunicación. En el mismo sentido las SSTC 51/1989, FJ 2. ${ }^{\circ}$, de 22 de febrero; y 121/1989, FJ 2. ${ }^{\circ}$, de 3 de julio.

63 También la Declaración de Derechos del Niño, aprobada por la Asamblea General de las Naciones Unidas, de 20 de noviembre de 1959; y la Resolución A3-0172/92, del Parlamento Europeo, que aprobó la Carta Europea de los Derechos del Niño. 
La libertad de información dirigida a los menores no sólo debe cumplir con la exigencia intrínseca de veracidad, sino que además se verá restringida por la exigencia de pluralidad y, en las comunicaciones con finalidad educativa, por el respeto a los principios constitucionales (LO 1/96, art. 5.2). Se impone a las Administraciones públicas que velen porque los medios de comunicación incentiven los mensajes que promuevan los valores de igualdad, solidaridad y respeto a los demás, eviten imágenes de violencia, explotación en las relaciones interpersonales o que reflejen un trato degradante o sexista (art. $5.3 \mathrm{LO} \mathrm{1/96).}$

El artículo 5.4, LO 1/96, habilita la creación de normas especiales que restrinjan los mensajes o la publicidad dirigida a menores para preservarles física y moralmente. Éstas ya existían en múltiples ámbitos materiales, como sanidad ${ }^{64} \mathrm{O}$ juguetería ${ }^{65}$; incluso, la Ley General de Publicidad ${ }^{66}$ declaraba ilícita la publicidad que atentara contra la infancia y la juventud y prohibía la referida a alcohol y tabaco, cuando a la misma pudiera acceder este sector de la población.

Finalmente, el artículo 186 del Código Penal limita la libertad de comunicación cuando el mensaje se refiera a material pornográfico, al disponer: "El que, por cualquier medio directo, difundiera, vendiere o exhibiere material pornográfico entre menores de edad o incapaces, será castigado con la pena de multa de tres a diez meses". En el mismo sentido, el artículo 189.1: "El que utilizaré a un menor de edad o a un incapaz con fines o en espectáculos exhibicionistas o pornográficos será castigado con la pena de prisión de uno a tres años". La extensión de la protección constitucional a los incapaces parece una analogía razonable.

Conflictos con otros bienes constitucionales

\section{a) El orden público protegido por la ley}

La resolución de estos conflictos no debe intentarse maximizando estos bienes generales y minimizando las libertades de comunicación. El conflicto con el orden público puede solucionarse admitiendo la defensa, propaganda y apología en abstracto del desorden y del delito y negando la instigación directa y concreta en la comisión de los $\operatorname{mismos}^{67}$.

64 El artículo 6. e) del Real Decreto 1416/1994 prohíbe la publicidad sobre medicamentos que "Se dirija, exclusiva o principalmente, a los niños".

65 Real Decreto 2330/1985, de 6 de noviembre, que establece normas de seguridad de juguetes, útiles de uso infantil y artículos de broma. Esta normativa dispone en su artículo 5: "Los mensajes publicitarios y cualquier información sobre juguetes no deben inducir a error sobre las características y garantías de seguridad de los mismos, ni sobre la capacidad y aptitudes necesarias en el niño para utilizar dichos juguetes sin producirse daño".

66 Ley 34/1988, de 11 de noviembre, artículos. 3 a) y 8.5.

67 En línea, por tanto, con el Tribunal Supremo de Estados Unidos en la Sentencia Terminello versus Chicago de 1949, tal y como propone SOLOZÁBAL ECHAVARRÍA, Juan José, "Aspectos constitucionales de la libertad de expresión..., ob. cit., pp. 241-243. 
El Código Penal de $1995^{68}$ confirma las afirmaciones que se acaban de realizar al tipificar, en su artículo 578, la provocación de los delitos de terrorismo. Para la doctrina penal este tipo implica ampliar la punición de los actos preparatorios de un delito y debe entenderse no como apología, sino como incitación directa a la comisión de actos violentos ${ }^{69}$.

En esta línea, la STC 159/1986, FFJ 6..$^{\circ}$ 7. ${ }^{\circ}$ y 8..$^{\circ}$ ampara la publicación en prensa de un comunicado apologético de la organización ETA Militar por tratarse de una mera reproducción, sin acompañar juicios de valor, y por la vertiente institucional que acompaña a la libertad de comunicación. Este pronunciamiento se apoya, además, en la necesidad de interpretar los límites a la libertad de comunicación restrictivamente; en asumir la interpretación más favorable al derecho fundamental; y en que los órganos judiciales no pueden interpretar la Ley Penal como un límite absoluto a la libertad de comunicación, con independencia de si el informador asuma o no comparta la actividad delictiva y supeditando un derecho fundamental a cualquier interés que pueda inspirar al legislador penal. Sobre este último aspecto, la STC 13/1985, FJ $3 .^{\circ}$, que se analizará con ocasión del secreto sumarial, aclara cuándo la ley penal puede limitar a un derecho fundamental. Finalmente la STC 195/1990, FJ $8 .^{\circ}$, al confrontar honor y libertad de expresión, confirma que el Código Penal sólo puede restringir un derecho fundamental si la tipificación del delito o falta buscan la protección de un derecho o bien constitucional.

La distinción entre apología e incitación directa al delito se confirma, también, cuando la libertad de comunicación es expresión de la libertad ideológica. Si se considera que la STC 20/1990, FJ 3..$^{\circ}$, dispuso que esta última libertad no tiene más límites en sus manifestaciones que la necesaria para el mantenimiento del orden público protegido por la ley. Y, posteriormente, en el FJ 5.', parece identificar este límite con la violencia: "La libertad ideológica indisolublemente unida al pluralismo político que, como valor esencial de nuestro ordenamiento jurídico propugna la Constitución, exige la máxima amplitud en el ejercicio de aquélla y, naturalmente, no sólo en lo coincidente con la Constitución y con el resto del ordenamiento jurídico, sino también en lo que resulte contrapuesto a los valores y bienes que en ellos se consagran, excluida siempre la violencia para imponer los propios criterios, pero permitiendo la libre exposición de los mismos en los términos que impone una de-

68 Ley Orgánica 10/1995, de 23 de noviembre.

69 PRATS CANUTS, José Miguel, Comentarios al nuevo Código Penal, dirigido por QUINTERO OLIVARES, Gonzalo, Ed. Aranzadi, Pamplona 1996, p. 2236, señala: “En la punición de los actos preparatorios se sigue la aplicación de la fórmula más amplia, a saber, la de tipificar no sólo los actos preparatorios propios conspiración y proposición sino también ampliarlo al acto preparatorio impropio, la provocación, lo cual plantea indudables problemas en relación a su manifestación de apología, de contornos muy imprecisos y siempre en conflicto con derechos de rango constitucional, como es el de la libertad de expresión y de información. En cualquier caso, a estos efectos recordar que tanto la organización como los fines de alteración del orden constitucional, carecen de significación penal si están desprovistos del recurso a medios violentos, por tanto ése debe ser el contenido de la apología y no otro". 
mocracia avanzada. De ahí la indispensable interpretación restrictiva de las limitaciones a la libertad ideológica y del derecho a expresarla, sin el cual carecería aquélla de toda efectividad ${ }^{70}$.

Los reducidos límites de la libertad de comunicación cuando ésta es expresión de la libertad ideológica se circunscriben a la libertad de expresión y esto se explica porque, según señala el FJ 5. ${ }^{\circ}$ de la STC 20/1990, al no estar ésta condicionada por la exigencia de veracidad es menos flexible y rigurosa la medida de sus limitaciones, que en el caso de la libertad de información ${ }^{71}$.

La anterior posición doctrinal coexiste con otra antagónica, representada por la STC 214/1991, FJ 8. ${ }^{\circ 72}$, donde, a propósito del pueblo judío y del holocausto, se afirma: "...ni la libertad ideológica...ni la libertad de expresión...comprenden el derecho a efectuar manifestaciones, expresiones o campañas de carácter racista o xenófobo", lo que sería contrario al derecho al honor (art. 18.1), a la dignidad de la persona (art. 10.1) y al valor de la igualdad (art. 1.1 en relación con el 14 todos ellos CE). Añadiendo: "...aun cuando, tal y como se ha reiterado, el requisito constitucional de la veracidad

70 El FJ 3..$^{\circ}$ contenía la justificación de estas afirmaciones: “...sin la libertad ideológica consagrada en el art. 16.1 de la Constitución, no serían posibles los valores superiores de nuestro ordenamiento jurídico que se propugnan en el art. 1.1 de la misma para constituir el Estado social y democrático de derecho que en dicho precepto se instaura. Para que la libertad, la justicia, la igualdad y el pluralismo político sean una realidad efectiva y no la enunciación teórica de unos principios ideales, es preciso que a la hora de regular conductas y, por tanto, de enjuiciarlas, se respeten aquellos valores superiores sin los cuales no se puede desarrollar el régimen democrático que nos hemos dado en la Constitución de 1978".

A continuación el fundamento añade lo que le permite llegar a las afirmaciones contenidas en el texto: «...la libertad ideológica invocada por el recurrente, por ser esencial, como hemos visto, para la efectividad de los valores superiores y especialmente del pluralismo político, hace necesario que el ámbito de este derecho no se recorte ni tenga más limitación (en singular utiliza esta palabra el art. 16.1 CE), en sus manifestaciones, que la necesaria para el mantenimiento del orden público protegido por la ley".

71 Esta doctrina es confirmada por la STC 105/1990, FJ 4. ${ }^{\circ}$, de 6 de junio, cuando señala que el campo de acción del art. 20.1 a) "se amplía aún más en el supuesto de que el ejercicio de la libertad de expresión afecte al ámbito de la libertad ideológica garantizada por el art. 16.1 C.E., según señalamos en nuestra STC 20/1990".

72 La STC 176/1995, de 11 de diciembre, difícilmente puede considerarse como continuadora de esta jurisprudencia por: tratarse de un cómic titulado "Hitler=SS"; incardinarse en el apartado b) del artículo 20 - los solicitantes de amparo reclaman la libertad artística y el FJ $5 .^{\circ}$ habla de "tratamiento predominantemente gráfico servido por un texto literario - , aunque la sentencia considere el cómic como manifestación de la libertad de expresión; estimarse que la publicación contiene "una densa carga de hostilidad que incita a veces directa y otras subliminalmente a la violencia por la vía de la vejación"; infligirse claras vejaciones y humillaciones al pueblo judío; apreciarse animus iocandi de la publicación; y por entenderse que el destinatario mayoritario habrán de ser niños y adolescentes que no tienen su personalidad formada, lo que, además, se opone a las directrices fijadas por la educación en el art. 27.2 CE. Debe considerarse también la ausencia de relevancia pública necesaria en la confrontación entre el honor y la libertad de comunicación.

No obstante, la sentencia llega a afirmar en el FJ $5 .^{\circ}$ : "La apología de los verdugos, glorificando su imagen y justificando sus hechos, a costa de la humillación de sus victimas no cabe en la libertad de expresión como valor fundamental del sistema democrático que proclama nuestra Constitución". 
objetiva no opera como límite en el ámbito de las libertades ideológicas y de expresión, tales derechos no garantizan, en todo caso, el derecho a expresar y difundir un determinado entendimiento de la historia o concepción del mundo con el deliberado ánimo de menospreciar y discriminar, al tiempo de formularlo, a personas o grupos por razón de cualquier condición o circunstancia personal, étnica o social, pues sería tanto como admitir que, por el mero hecho de efectuarse al hilo de un discurso más o menos histórico, la Constitución permite la violación de uno de los valores superiores del ordenamiento jurídico, como es la igualdad (art. 1.1 CE) y uno de los fundamentos del orden político y de la paz social: la dignidad de la persona (art. 10.1 CE)".

Con esta segunda doctrina por fundamento el Código Penal de 1995 estableció en su artículo 607: «1. Los que, con propósito de destruir total o parcialmente a un grupo nacional, étnico, racial o religioso, [...] serán castigados... 2. La difusión por cualquier medio de ideas o doctrinas que nieguen o justifiquen los delitos tipificados en el apartado anterior de este artículo o pretendan la rehabilitación de regímenes o instituciones que amparen prácticas generadoras de los mismos, se castigará con la pena de prisión de uno a dos años".

Esta segunda doctrina jurisprudencial, y la aplicación del Código Penal en este sentido, han sido duramente criticadas por la doctrina. En mi opinión, El FJ 8..$^{\circ}$ de la STC 214/1991 entra en contradicción con los fundamentos $6 .^{\circ}$ y $7 .^{\circ}$ de la propia sentencia, que sintetizan la jurisprudencia anterior a propósito de la libertad de comunicación y, más específicamente, del conflicto entre la libertad de expresión y el honor. A modo de ejemplo, el insulto o la expresión gravemente injuriosa, utilizados como límite a la libertad de expresión, se sustituyen por expresiones utilizadas en descrédito o menosprecio y por juicios ofensivos. Para, a continuación, en un salto hacia adelante, ampliar la restricción a las manifestaciones o expresiones de carácter racista o xenófobo, apoyándose en el honor, la dignidad y la igualdad y sin ponderar estos bienes constitucionales con los reflejados en la primera línea doctrinal. Finalmente, en un nuevo salto con idéntica apoyatura, se prohíbe el revisionismo histórico.

Las sucesivas sentencias del Tribunal olvidarán las reglas de ponderación empleadas en el FJ 8..$^{\circ}$ para resolver el conflicto entre libertad de comunicación y derechos de la personalidad. Incluso, la STC 43/2004, FJ $5 .^{\circ}$ y $6 .^{\circ}$, tras precisar que el apartado b) del artículo $20 \mathrm{CE}$ es una mera concreción del a), realiza afirmaciones que suponen, a mi juicio, una clara rectificación de la STC 214/1991, aquí analizada: "Pues bien, es posible colegir que la libertad científica —en lo que ahora interesa, el debate histórico- disfruta en nuestra Constitución de una protección acrecida respecto de la que opera para las libertades de expresión e información, ya que mientras que éstas se refieren a hechos actuales protagonizados por personas del presente, aquélla, participando también de contenidos propios de las libertades de expresión e información - pues no deja de ser una narración de hechos y una expresión de opiniones y valoraciones y, en consecuencia, información y libre expresión a los efectos del art. 20.1 a) y d) CE - se refiere siempre a hechos del pasado y protagonizados por individuos cuya personalidad, en el sentido constitucional 
del término (su libre desarrollo es fundamento del orden político y de la paz social: art. $10.1 \mathrm{CE}$ ), se ha ido diluyendo necesariamente como consecuencia del paso del tiempo y no puede oponerse, por tanto, como límite a la libertad científica con el mismo alcance e intensidad con el que se opone la dignidad de los vivos al ejercicio de las libertades de expresión e información de sus coetáneos. Por lo demás, sólo de esta manera se hace posible la investigación histórica, que es siempre, por definición, polémica y discutible, por erigirse alrededor de aseveraciones y juicios de valor sobre cuya verdad objetiva es imposible alcanzar plena certidumbre, siendo así que esa incertidumbre consustancial al debate histórico representa lo que éste tiene de más valioso, respetable y digno de protección por el papel esencial que desempeña en la formación de una conciencia histórica adecuada a la dignidad de los ciudadanos de una sociedad libre y democrática». Y añade en el FJ 6.': «Si la historia solamente pudiera construirse con base en hechos incuestionables, se haría imposible la historiografía, concebida como ciencia social. En su ámbito, los historiadores valoran cuáles son las causas que explican los hechos históricos y proponen su interpretación, y aunque tales explicaciones e interpretaciones sean en ocasiones incompatibles con otras visiones, no corresponde a este Tribunal decidir, por acción u omisión, cuál o cuáles deban imponerse de entre las posibles. Son los propios ciudadanos quienes, a la luz del debate historiográfico y cultural, conforman su propia visión de lo acaecido, que puede variar en el futuro".

Se debe recordar, además, que nuestra Norma Fundamental no contiene un sistema de defensa de la Constitución ${ }^{73}$ y que ésta es íntegramente reformable $^{74}$, por lo que no puede prohibirse la defensa abstracta de objetivos, cuya consecución, en cambio, está permitida.

\section{b) El secreto sumarial}

La STC 13/1985, FJ 3..$^{\circ}$, establece "que la regulación legal del secreto sumarial no se interpone como un límite frente a la libertad de información, sino

73 Véase GARCÍA GUERRERO, José Luis, "Algunas cuestiones sobre la constitucionalización de los partidos políticos", Revista de Estudios Políticos, núm. 70, 1990, p. 150 y la amplia nota 16; así como las SSTC 101/1982, FJ 5. , de 18 de noviembre; 122/1983, de 16 de diciembre; y, muy especialmente, la 48/2003, FJ $13 .^{\circ}$, de 12 de marzo, que descarta rotundamente, con ocasión de examinar la constitucionalidad de la Ley de Partidos Políticos, que pueda caber en nuestro ordenamiento un sistema de defensa de la Constitución

74 ARAGÓN REYES, Manuel, Constitución y Democracia, Tecnos, Madrid, 1989, pp. 34 y ss., se pronuncia por la íntegra reformabilidad material de la Constitución. Sin entrar en polémicas doctrinales, me remito a las opiniones de este autor con las que coincido totalmente.

Sobre este punto véase DE VEGA, Pedro, La reforma constitucional y la problemática del poder constituyente, Tecnos, Madrid, 1985; PÉREZ ROYO, Javier, Reforma de la Constitución, 1987; JIMÉNEZ CAMPO, Javier, "Algunos problemas de interpretación en torno al título X de la Constitución", Revista de Derecho político, núm. 7, 1980; y GONZÁLEZ ENCINAR, José Juan, "La Constitución y su reforma", Revista Española de Derecho Constitucional, núm. 17, 1986. 
más amplia y genéricamente, como un impedimento al conocimiento por cualquiera incluidas las partes...". La restricción respeta las previsiones del artículo 20.4 CE al encontrar fundamento en otros derechos constitucionales del propio título —el proceso penal, el principio inquisitivo y el secreto sumarial están al servicio de una más efectiva represión del delito, que se tipifica precisamente para proteger a los aludidos derechos-; estar prevista en la Ley de Enjuiciamiento Criminal, interpretada conforme a los tratados internacionales; y realizar una adecuada concordancia práctica de derechos como seguidamente se observará.

La concordancia práctica es acertada y proporcional, porque la limitación al artículo $20 \mathrm{CE}$ es "sólo de modo derivado, es decir en la medida en que aquello que se quiera difundir o comunicar haya sido obtenido ilegítimamente, quebrando el secreto mismo del sumario". "...El secreto del sumario no significa, en modo alguno, que uno o varios elementos de la realidad social... sean arrebatados a la libertad de información, con el único argumento de que sobre aquellos elementos están en curso unas determinadas diligencias sumariales". "...Una información obtenida antes y al margen del sumario no puede considerarse atentatoria al secreto sumarial, que sólo limita la libertad de información en cuanto para informar haya previamente que quebrantarlo".

\section{c) La autoridad de los Jueces}

La STC 46/1988, estima que la libertad de expresión encuentra un límite en "la autoridad de las instituciones públicas, cuya función se ve entorpecida u obstaculizada cuando, injustificadamente o con ligereza, se ataca la honorabilidad o se pone en cuestión la honestidad de sus titulares" sobre todo si advierte que las manifestaciones "tratan de lesionar o menospreciar la competencia profesional de un Juez en ejercicio" (FJ 7. ${ }^{\circ}$. . Se pueden criticar las resoluciones jurisdiccionales, pero no se admite la «descalificación personal contra el Juez" si no es necesario para realizar la primera actividad ${ }^{75}$.

75 El conflicto entre la autoridad de los jueces y la libertad de expresión en el ejercicio de la defensa letrada conoce de una abundante jurisprudencia desde la STC 38/1988, FJ $2 .^{\circ}$ y $3 .^{\circ}$, de 9 de marzo; encontrando las críticas de la defensa un límite en las descalificaciones personales. La STC 155/2006, FJ 4. ${ }^{\circ}$, de 22 de mayo, señala: "que el ejercicio de la libertad de expresión en el seno del proceso judicial por los Letrados de las partes, en el desempeño de sus funciones de asistencia técnica, posee una singular cualificación, al estar ligado estrechamente a la efectividad de los derechos de defensa del art. 24 CE (STC 113/2000, de 5 de mayo, FJ 4)". También se indica que "consiste en una libertad de expresión reforzada cuya específica relevancia constitucional deviene de su inmediata conexión con la efectividad de otro derecho fundamental, el derecho a la defensa de la parte (art. 24.2 CE) y al adecuado funcionamiento de los órganos jurisdiccionales en el cumplimiento del propio y fundamental papel que la Constitución les atribuye (art. $117 \mathrm{CE}$ ) y y, por ello, se señala que "se trata de una manifestación especialmente inmune a las restricciones que en otro contexto habrían de operar (STC 205/1994, de 11 de julio, FJ 5)n. Asimismo se recuerda en la citada doctrina (SSTC 65/2004, FJ 2, 197/2004, FJ 5, 22/2005, FJ 3, y 232/2005, FJ 3) que "la especial cualidad de la 
El FJ 3. ${ }^{\circ}$, al confrontar honor y libertad de expresión, señala que en la ponderación debe tenerse presente "si la crítica tenía lugar respecto de los actos o resoluciones (en este caso del Juez) o en relación con la persona misma de quien ellos procedían [...] Consideración básica para discernir en casos como éste, por una parte, si la crítica se dirige contra la sentencia o resolución judicial o contra la persona o personas que la dictaron; y por otra si cabe calificarla realmente de crítica o por sus características se trata simplemente de expresiones o informaciones dirigidas al desmerecimiento de la persona".

Por su parte, el FJ $5 .^{\circ}$ se apoya en la STEDH de 24 de febrero de 1997, Caso Haes et Gijsels c., que afirma: "la acción de los Tribunales, que son garantes de la justicia y cuya misión es fundamental en un Estado de Derecho, tiene necesidad de la confianza del público y también conviene protegerla contra los ataques carentes de fundamento, sobre todo cuando el deber de reserva impide a los Magistrados reaccionar ${ }^{76}$.

\section{LA PUBLICIDAD COMERCIAL}

$\mathrm{Al}$ inicio del trabajo se ha indicado que en nuestro sistema jurídico existen diversas formas de comunicación caracterizadas por su objeto; es decir, por la materia a que se refieren, que no han merecido una constitucionalización expresa. Se ha defendido que el objeto de la libertad de comunicación, en directa relación con la teoría que le sirve de fundamento, es indeterminado y, por tanto, cubre todo tipo de ámbitos materiales. Y se ha propuesto explicar las escasas restricciones del discurso político y las grandes limitaciones a la publicidad comercial o a la pornografía, empleando, como primera pauta, las conexiones sistemáticas constitucionales que vienen dadas por la materia a que se refiere el mensaje y la finalidad que persigue, y, como segunda, el interés público de la comunicación para formar la opinión de una sociedad moderna. Con estos antecedentes, se está en condiciones de afrontar dos de las materias más controvertidas en el derecho comparado a la hora de ser incluidas bajo la protección de la libertad de comunicación y que, además, sufren las mayores restricciones: la publicidad comercial, y el erotismo y la pornografía.

libertad de expresión del Abogado en el ejercicio de defensa de su patrocinado debe valorarse en el marco en el que se ejerce y atendiendo a su funcionalidad para el logro de las finalidades que justifican su privilegiado régimen, sin que ampare el desconocimiento del respeto debido a las demás partes presentes en el procedimiento y a la autoridad e imparcialidad del Poder Judicial, que el art. 10.2 del Convenio europeo de derechos humanos erige en límite explícito a la libertad de expresión (SSTC 205/1994, de 11 de julio, FJ 5; 157/1996, de 15 de octubre, FJ 5; 226/2001, de 26 de noviembre, FJ 2; 79/2002, FJ 6; STEDH de 22 de febrero de 1989, caso Barfod)".

Véase la más reciente y consolidada jurisprudencia constitucional: SSTC 113/2000, FJ 4. ${ }^{\circ}$, de 5 de mayo; $117 / 2003$, FJ $3 .^{\circ}$ de 16 de junio; $65 / 2004$, FJ $3 .^{\circ}$, de 19 de abril; 232/2005, FJ $3 .^{\circ}$ Y $4 .^{\circ}$, de 26 de septiembre; 338/2006, FJ $2 .^{\circ}$ y $3 .^{\circ}$, de 11 de diciembre; $24 / 2007$, FJ $2 .^{\circ}$ y $3 .^{\circ}$, de 12 de febrero. Véase, también, supra nota 5.

76 Véase sobre esta materia la STC 121/1989, de 3 de julio, y en relación con la misma a SALVADOR CODERCH, Pablo, El Mercado de las ideas, ob. cit., pp. 101 y ss. 
En el ordenamiento jurídico constitucional español dentro del género de la propaganda debe diferenciarse, por su ámbito material y finalidad, tres de sus especies, estrechamente ligadas entre sí: la propaganda política, regulada, principalmente, en la LOREG $^{77}$; la propaganda institucional, emitida por los distintos órganos y entes del Estado; y, por último, aquella que merece en este momento nuestra atención, la publicidad $\operatorname{comercial}^{78}$, aunque sería más correcto terminológicamente prescindir del adjetivo.

Nuestro Tribunal Constitucional ha negado que los mensajes publicitarios se encuentren tutelados por la libertad de información. No obstante, el pronunciamiento es tan incidental que no cabe hablar de una posición doctrinal ${ }^{79}$. Por el contrario, sí cabe hacerlo en lo que respecta al Tribunal Europeo de Derechos Humanos (TEDH).

Este órgano jurisdiccional ha afirmado rotundamente que la publicidad comercial esta protegida por la libertad de comunicación, concretamente, en la STEDH de 24 de febrero de 1995, caso Casado Coca, que no deja de ser una recopilación de los fundamentos doctrinales aportados en fallos anteriores. Concretamente, en el fundamento 35 el Tribunal reconoce que aunque en el caso Barthold había dejado abierta la cuestión de si la publicidad comercial, como tal, se encontraba protegida por el artículo 10 en su jurisprudencia posterior aporta indicios sobre la materia: en el caso Markt Intern establece que el artículo 10 no se aplica sólo a ciertos tipos de información o ideas o formas de expresión, en particular a los de naturaleza política; sino que ampara también las expresiones artísticas (caso Müller), la información de naturaleza comercial (caso Markt Intern) e, incluso, música ligera y emisiones publicitarias transmitidas por cable (caso Groppera Radio AG y otros) ${ }^{80}$.

La razón básica de la tutela descansa en que aunque un mensaje persiga una finalidad exclusivamente publicitaria, aporta también información sobre las características de los bienes y servicios. Además, la necesidad de preservar ésta aumenta en la medida en que se beneficia a los consumidores.

77 Ley Orgánica 5/85, de 19 de junio, del Régimen Electoral General (BOE 200186). Posteriormente ha sufrido numerosas modificaciones. Esta ley utiliza indistintamente los términos propaganda y publicidad, si bien parece reservarse la primera para actuaciones en que intervienen organismos o entes de Derecho público, y la segunda para designar las relaciones entre las candidaturas y los medios de difusión de carácter privado, especialmente en lo que a contratación se refiere.

78 Su regulación básica se encuentra en la Ley 34/1988, de 11 de noviembre, General de Publicidad.

79 STC 87/1987, FJ 4, de 2 de junio. En el mismo sentido la Providencia de la Sección 4. ${ }^{a}$, Sala $2 .^{a}$, de 17 de abril de 1989, que inadmitió un recurso de amparo.

El Tribunal Supremo ha negado que la libertad de expresión tutele a la publicidad. Véase la sentencia de 23 de septiembre de 1988 (Sala 4. ${ }^{a}$, Repertorio de Jurisprudencia Aranzadi núm. 7252); confirmada en la sentencia de 18 de febrero de 1994 (Actualidad Jurídica Aranzadi, núm. 146, 21 de abril de 1994, p. 8)

80 Véase GARCÍA GUERRERO, José Luis, "La publicidad comercial en la convención europea para la protección de los derechos humanos", Revista General del Derecho, 1998, pp. 1069910725. 
A idéntica conclusión habría que llegar en nuestro ordenamiento ${ }^{81}$; si se considera que la jurisprudencia del TEDH constituye un valor hermenéutico preferente en virtud del artículo 10.1 CE y que el Convenio de Roma forma parte de nuestro derecho interno y sus normas son directamente aplicables por las autoridades administrativas y judiciales, al haber sido publicadas en España conforme establece el artículo. 96.1 CE.

La publicidad se enmarcaría, probablemente, en el apartado d) del artículo. $20 \mathrm{CE}^{82}$, si se considera que el informativo es el elemento predominante dentro del mensaje publicitario y que como ha afirmado la STC 51/1997, FJ 4. ${ }^{\circ}$, cuando en la transmisión de un mensaje predominan los hechos se está en presencia de la libertad de información, aunque el emitente pretenda o tenga por finalidad que de la comunicación se deduzcan determinados juicios de valor $^{83}$. Aunque hay que tener presente que este fallo no se refería expresamente a la publicidad.

\section{El EROTISMO Y LA PORNOGRAFÍA}

Ya se ha señalado que la libertad de comunicación es un derecho libertad, por lo que su objeto es indeterminado. No hay limitaciones por razón de la materia sobre la que verse la comunicación. En consecuencia, el erotismo y la pornografía se encuentran protegidos por el artículo 20 CE. Por esta razón, probablemente, el nuevo Código Penal elimina antiguos tipos penales que permitían reprimir estas comunicaciones (delitos de escándalo público — artículos 431 y 432 y la falta de imprenta artículo 566.5).

En un principio la jurisprudencia constitucional no parecía entenderlo de esta forma. La STC 62/1982, FJ 3..$^{\circ}$, consideró que la pornografía "aunque no siempre y en todos los casos" (FJ 5..$^{\circ}$, se está refiriendo expresamente a la ex-

81 En este sentido se pronuncia la doctrina científica española que más exhaustivamente ha estudiado la cuestión. Véase GARCÍA GUERRERO, José Luis, "Publicidad y libertad de expresión...", ob. cit., pp. 117-146; y "La publicidad como vertiente de la libertad de expresión en el ordenamiento constitucional español", Revista Española de Derecho Constitucional, núm. 50, 1997, pp. 77-101. También, MUÑOZ MACHADO, Santiago, "Advertising in the Spanish Constitution", en el libro, Advertising and Constitutional Rights in Europe, dirigido por SKOURIS, Wassilios, Nomos Verlagsgesellschaft, BadenBaden, 1994, p. 314; y SANTAELLA, Manuel, El nuevo derecho de la publicidad, Civitas, Madrid, 1992, pp. 33, 55 y 119-120.

82 GARCÍA GUERRERO, José Luis, "Publicidad y...”, ob. cit., pp. 142 y ss.; MUÑOZ MACHADO, Santiago, "Advertising in the Spanish Constitution", ob. cit., p. 314; VILLAVERDE MENÉNDEZ, Ignacio, Estado democrático e información..., ob. cit., p. 202; SANTAELLA, Manuel, El nuevo derecho..., ob. cit., pp. 55 y 119-120; y GARITAONANDÍA, Carmelo, "La publicidad y las normas reguladoras de la publicidad en Euskal Irrati Telebista Radiotelevisión Vasca y en Radiotelevisión Española", Revista Vasca de Administración Publica, núm. 9, p. 365; incluyen a la publicidad en el apartado d) del artículo 20.

83 La STC 126/1990, FJ 3. ${ }^{\circ}$, de 5 de julio, en un supuesto similar, se inclinaba por considerar que el mensaje estaba protegido simultáneamente por los apartados a) y d) del artículo 20 CE. No obstante, ya permitía anticipar el contenido de la reseñada en el texto. 
hibición de películas de este género en salas X era contraria a la moral y que este concepto podía limitar a la libertad de expresión si se utilizaban las previsiones del Convenio de Roma y de diversos Tratados internacionales ratificados por España; sobre todo, si se considera que el artículo 10.2 CE prescribe que los derechos y libertades fundamentales se interpreten conforme a estas normas internacionales. El Tribunal previamente había argumentado que el artículo 20.4, en conexión con el 53.1 CE, permiten que la ley limite la libertad de comunicación siempre que no se afecte el contenido esencial de ésta.

Este aislado pronunciamiento no parece que pueda tener vigencia, hoy, si se tienen presentes los principios generales que inspiran la libertad de comunicación, ya reseñados; la desaparición de los tipos penales; y, en mi opinión, dos inexactitudes contenidas en la sentencia: En primer lugar, el convenio de Roma es utilizado como ratio decidendi por la sentencia para introducir en nuestro ordenamiento la moral como límite a la libertad de comunicación; sin embargo, el artículo 53 de este instrumento normativo rechaza que el mismo pueda ser empleado para la restricción de cualquier derecho por un estado contratante ${ }^{84}$. En segundo lugar, el artículo 20.4 admite, con o sin conexión con el 53.1 CE, que la libertad de comunicación pueda limitarse al entrar en conflicto con otros derechos constitucionales del Título I o con las leyes que directamente desarrollen a éstos; pero, en ningún caso, habilita al legislador para que éste, sin previsión constitucional expresa o implícita, restrinja la libertad analizada, como podría deducirse del ambiguo FJ $3 .^{\circ}$; y ello aunque se respetará el contenido esencial.

La interpretación de los derechos y libertades fundamentales conforme a los Tratados internacionales, que dispone el artículo $10.2 \mathrm{CE}$, no parece base suficiente para extraer de los mismos limitaciones que se introduzcan ex novo en nuestro ordenamiento constitucional; a ello se opone también el favor libertatis que preside la interpretación en la materia y la propia naturaleza de los Tratados que constituyen un minimum en el disfrute de los referidos derechos. La STC 13/1985, FJ 3..$^{\circ}$, parece seguir la posición aquí defendida, al señalar que las limitaciones sólo se justifican si pretender preservar otro bien constitucional, pese a que los órganos judiciales, que motivan el amparo, habían extraído la restricción de los Tratados internacionales.

Posteriormente, al resolver un conflicto de competencias, la STC 49/1984, FFJ $4 .^{\circ}$ y $7 .^{\circ}$, admite la constitucionalidad de una legislación hoy superada que restringe el ejercicio de la libertad de comunicación, al limitar la exhibición de películas pornográficas o que realizan apología de la violencia. Se trata de una línea jurisprudencial que avanza en una actitud más liberal y con-

84 Artículo 53. Protección de los derechos humanos reconocidos. - Ninguna de las disposiciones del presente Convenio será interpretada en el sentido de limitar o perjudicar aquellos derechos humanos y libertades fundamentales que podrían ser reconocidos conforme a las leyes de cualquier Alta Parte Contratante o en cualquier otro Convenio en el que ésta sea parte. En contra, FRANCESC DE CARRERAS, "la libertad de expresión...", ob. cit., p. 34. 
forme con la Constitución por fundamentar las limitaciones, principalmente, en la protección de la infancia y la juventud (FFJ $4 .^{\circ}$ y $7 .^{\circ}$ ) e, incidentalmente, en "la sensibilidad moral del espectador medio" (FJ $4 .^{\circ}$ ); por que la limitación se refiere al modo de ejercicio del derecho — se restringe esta actividad a las salas X y se desincentiva mediante medidas económicas (presiones fiscales y exclusión de ayudas estatales-; y, finalmente, por que la prohibición absoluta se limita a denegar el acceso a estas salas a los menores de edad.

Finalmente la STC 52/1995, FJ $4 .^{\circ}$ y $5 .^{\circ}$, confirma la protección de la libertad de expresión a la difusión de revistas pornográficas; las limitaciones a estos derechos deben estar basadas en bienes constitucionales, ser proporcionales y establecerse por ley. La STC 176/1995, ya en línea con los nuevos criterios, justifica la condena penal al editor de un cómic pornográfico, entre otros motivos, porque los destinatarios eran niños y adolescentes y por las directivas que el artículo 27.2 CE impone a la educación.

ABstRaCT. The present Project contains a complete synthesis of the constitutional Spanish jurisprudence. The author considers that the right to freedom and the political rights are grouped around three or four genres. It identifies, between those, the freedom of communication that the constitutional assembly and the constitutional jurisprudence have extended to all sorts of activities. After this assumption, the project is focused on giving a view of the freedom of communication from the point of view of the differences between the freedom of information and the freedom of speech in a strict way. After defending a legal nature which protects all kinds of communications and which can be exercised by all sorts of chaps; it is rejected that the institutional offshoot explains the really different limitations that several messages introduce, wide restrictions regarding commercial speech or pornography and dropped ones regarding politics. The argument which is proposed for its justification is based on the different systematic connections that are originated between the constitutional rules by the different matter and the purpose pursued by the messages, and, when this yardstick is insufficient, it is complemented with the concept of relevance or public interest, the one which is pretended to be refined. The exercise of that freedom by journalists and maximizing the professional diligence reinforce the freedom of communication when it has to be pondered with other rights or constitutional goods. In Spain, the affair Terminello versus Chicago is considered as a worth yardstick to solve conflicts with the public order. 